WSRC-TR-2003-00080

Rev. 0

\title{
Porous Medium Analysis of Tank 41 Drain Operations (U)
}

G. P. Flach

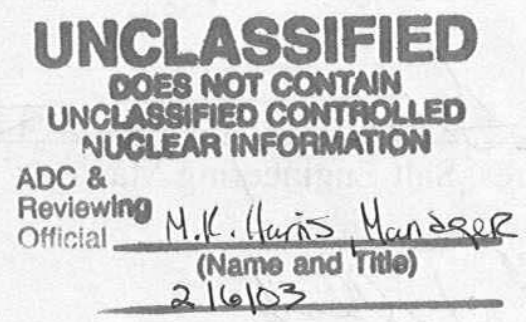

Westinghouse Savannah River Company

Savannah River Site

Aiken, SC 29808

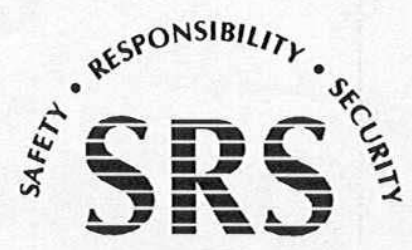

SAVANNAH RIVER SITE 
This document was prepared in conjunction with work accomplished under Contract No. DE-AC09-96SR18500 with the U. S. Department of Energy.

\section{DISCLAIMER}

This report was prepared as an account of work sponsored by an agency of the United States Government. Neither the United States Government nor any agency thereof, nor any of their employees, makes any warranty, express or implied, or assumes any legal liability or responsibility for the accuracy, completeness, or usefulness of any information, apparatus, product or process disclosed, or represents that its use would not infringe privately owned rights. Reference herein to any specific commercial product, process or service by trade name, trademark, manufacturer, or otherwise does not necessarily constitute or imply its endorsement, recommendation, or favoring by the United States Government or any agency thereof. The views and opinions of authors expressed herein do not necessarily state or reflect those of the United States Government or any agency thereof.

This report has been reproduced directly from the best available copy.

Available for sale to the public, in paper, from: U.S. Department of Commerce, National Technical Information Service, 5285 Port Royal Road, Springfield, VA 22161, phone: (800) 553-6847, fax: (703) 605-6900

email: orders@ntis.fedworld.gov

online ordering: http://www.ntis.gov/help/index.asp

Available electronically at http://www.osti.gov/bridge

Available for a processing fee to U.S. Department of Energy and its contractors, in paper, from: U.S. Department of Energy, Office of Scientific and Technical Information, P.O. Box 62, Oak Ridge, TN 37831-0062,

phone: (865)576-8401,

fax: (865)576-5728

email: $\underline{\text { reports@ adonis.osti.gov }}$ 


\section{Executive Summary}

Under the Low Curie Salt Program, interstitial liquid is being drained from saltcake in Tank 41 to remove most of the Cs-137 activity. After the liquid content in saltcake approaches the residual saturation level, the tank will be re-flooded to a level 2" above the saltcake level. Then at least 30" of saltcake will be dissolved off the top and disposed of as saltstone according to near-term plans. The program is contingent upon reducing residual liquid content, and thus residual Cs-137 content, to a sufficiently low level. High Level Waste requested assistance from the Savannah River Technology Center in analyzing drain operations from 9/8/02 through 12/9/02 to better understand the interstitial liquid level profile across the tank, and the liquid saturation profile from tank bottom to top.

A static gravity-equilibrium analysis of the well level before and after net removal of 113,000 gallons of liquid indicates the drainable water content of Tank 41 saltcake is in the range of 13-18 volume percent, with a best-estimate of $14 \%$. Over a time scale of several days for drainage, the drainage porosity is close to $13 \%$. For longer drain times and higher elevations above the interstitial liquid level and capillary fringe, the effective drainage porosity may be higher, possibly approaching $18 \%$, due to additional drainage. Several non-unique combinations of assumed porosity and residual saturation can produce a drainage porosity of $14 \%$. Therefore, the drainage data by itself are insufficient to define the residual liquid content. Additional information in the form of a total porosity estimate or a residual saturation estimate is needed to define the residual liquid content after drainage. Some example combinations of initial and residual water content that produce a drainage porosity of $14 \%$ are shown below:

\begin{tabular}{|c|c|c|c|c|c|}
\hline \multirow{2}{*}{$\begin{array}{c}\text { Initial water } \\
\text { content in } \\
\text { submerged } \\
\text { saltcake } \\
\theta_{\text {ws }}\end{array}$} & \multicolumn{5}{|c|}{ Radiolytic gas lumped with salt - excluded from "voids" } \\
\hline & $\begin{array}{c}\text { Pseudo total } \\
\text { porosity } \\
\text { n' }\end{array}$ & $\begin{array}{c}\text { Drainable } \\
\text { liquid content } \\
\left.\text { n'(1-S }{ }_{w r}\right)\end{array}$ & $\begin{array}{c}\text { Residual } \\
\text { liquid content } \\
\text { n'S }_{\mathrm{wr}} \text { ' }\end{array}$ & $\begin{array}{c}\text { Pseudo } \\
\text { residual } \\
\text { saturation } \\
\mathrm{S}_{\mathrm{wr}}\end{array}$ & $\begin{array}{c}\text { Pseudo } \\
\text { drainable } \\
\text { saturation } \\
1-S_{w r}\end{array}$ \\
\hline 0.20 & 0.20 & 0.14 & 0.06 & 0.30 & 0.70 \\
\hline 0.25 & 0.25 & 0.14 & 0.11 & 0.44 & 0.56 \\
\hline 0.30 & 0.30 & 0.14 & 0.16 & 0.53 & 0.47 \\
\hline 0.35 & 0.35 & 0.14 & 0.21 & 0.60 & 0.40 \\
\hline 0.40 & 0.40 & 0.14 & 0.26 & 0.65 & 0.35 \\
\hline
\end{tabular}

\begin{tabular}{|c|c|c|c|c|c|c|c|c|}
\hline \multirow{2}{*}{$\begin{array}{c}\text { Initial water } \\
\text { content in } \\
\text { submerged } \\
\text { saltcake } \\
\theta_{\text {ws }}\end{array}$} & \multicolumn{8}{|c|}{ Radiolytic gas included in void space } \\
\hline & $\begin{array}{c}\text { Initial gas } \\
\text { content } \\
\theta_{\mathrm{g}} \\
\end{array}$ & $\begin{array}{c}\text { Total porosity } \\
\mathrm{n}\end{array}$ & $\begin{array}{c}\text { Drainable } \\
\text { liquid content } \\
\mathrm{n}\left(\mathrm{S}_{\mathrm{ws}}-\mathrm{S}_{\mathrm{wr}}\right)\end{array}$ & $\begin{array}{c}\text { Residual } \\
\text { liquid content } \\
\mathrm{nS}_{\mathrm{wr}}\end{array}$ & $\begin{array}{c}\text { Initial } \\
\text { saturation } \\
\mathrm{S}_{\mathrm{ws}}\end{array}$ & $\begin{array}{c}\text { Residual } \\
\text { saturation } \\
\mathrm{S}_{\mathrm{wr}}\end{array}$ & $\begin{array}{c}\text { Drainable } \\
\text { saturation } \\
\mathrm{S}_{\mathrm{ws}}-\mathrm{S}_{\mathrm{wr}}\end{array}$ & $\begin{array}{c}\text { Gas } \\
\text { saturation } \\
\mathrm{S}_{\mathrm{g}}\end{array}$ \\
\hline 0.20 & 0.105 & 0.31 & 0.14 & 0.06 & 0.66 & 0.20 & 0.46 & 0.34 \\
\hline 0.25 & 0.105 & 0.36 & 0.14 & 0.11 & 0.70 & 0.31 & 0.39 & 0.30 \\
\hline 0.30 & 0.105 & 0.41 & 0.14 & 0.16 & 0.74 & 0.40 & 0.35 & 0.26 \\
\hline 0.35 & 0.105 & 0.46 & 0.14 & 0.21 & 0.77 & 0.46 & 0.31 & 0.23 \\
\hline 0.40 & 0.105 & 0.51 & 0.14 & 0.26 & 0.79 & 0.51 & 0.28 & 0.21 \\
\hline
\end{tabular}

A semi-empirical analysis of dynamic liquid levels during pumping suggests that mean tank level can be related to well level and pumping rate under pseudo-steady flow 
conditions (slow transients). The correlation appears to be reasonably accurate at predicting the equilibrium liquid level after 2-3 weeks of downtime. The mean tank level is expected to be a reasonable surrogate for the peak tank level, given that the largest gradients are at the well. However, the flow model considers only the effect of leveling of the interstitial liquid level, and not continued drainage from unsaturated saltcake above the liquid level. Thus long-term recovery will be somewhat higher than predicted by the flow model. In addition, the time required for tank liquid level to reach equilibrium after transient pumping at a well can be roughly estimated from the flow model. This information can be used to estimate the time required to drain residual amounts of liquid from the tank bottom. 


\section{Contents}

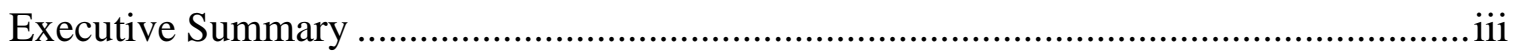

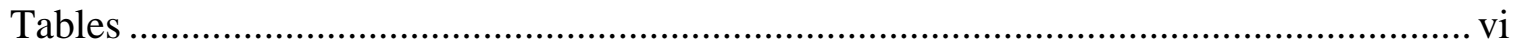

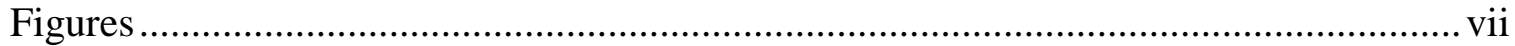

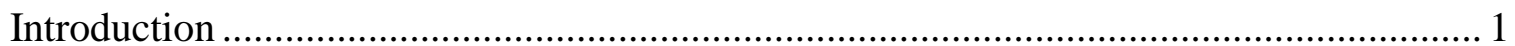

Tank 41 drawdown and well recovery data ........................................................ 1

Static gravity-equilibrium analysis of pre- and post-drain tank level ............................ 3

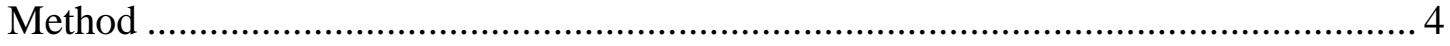

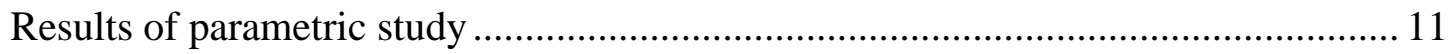

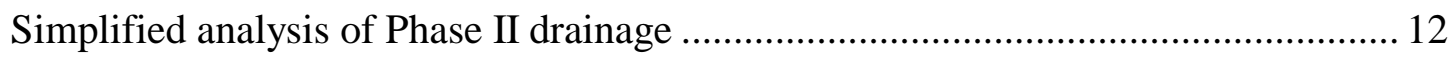

Analysis of dynamic tank liquid levels during drain operations .................................. 21

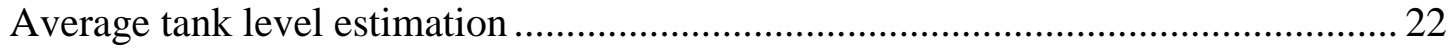

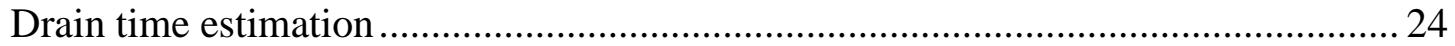

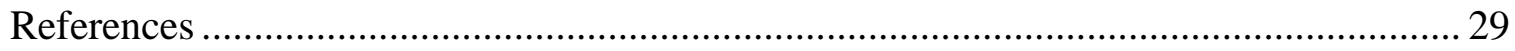




\section{Tables}

Table $1 \quad$ Net liquid removal during Tank 41 drain operations from 9/8/02 through 12/9/02 .............................................................................. 2

Table 2 Cross-sectional area of Tank 41 at various elevations ............................. 8

Table 3 van Genuchten (1980) parameters for various soils as defined by Schaap and Leij (1998)................................................................ 9

Table 4 Mass balance results for $10 \%$ initial water content, "Sand" water retention, and a 350" saltcake level ......................................................... 15

Table 5 Results of total porosity/water retention parameter study for 350" saltcake level; table shows the percentage deviation between the modeled liquid inventory change and the actual net volume of liquid removed from Tank 41

Table 6 Results of total porosity/water retention parameter study for a 345" saltcake level; table shows the percentage deviation between the modeled liquid inventory change and the actual net volume of liquid removed from Tank 41

Table 7 Drainage porosity estimate based in Phase II of Tank 41 drain operations

Table 8 Drainage porosity estimates based on optimal results from parametric study summarized by Tables 5 and 6 19

Table 9 Example combinations of initial and residual liquid content that are consistent with a $14 \%$ drainable liquid content; equivalent calculations shown for radiolytic gas excluded from and included in voids

Table 10 Calibration of pseudo-steady flow solution to Tank 41 data 


\section{Figures}

Figure $1 \quad$ Well drawdown and recovery data for Tank 41 between 9/8/02 and

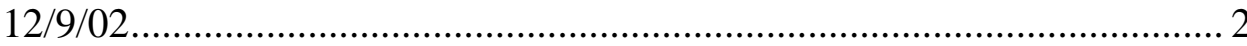

Figure 2 Well recovery curve with logarithmic forecast ..................................... 3

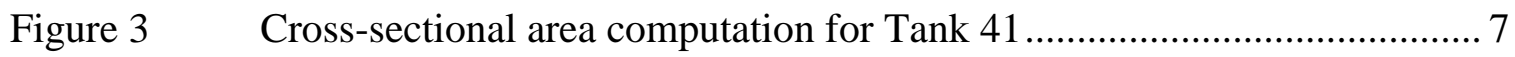

Figure 4 Water retention curve corresponding to varying capillary rise with varying pore sizes in a porous medium; reproduced from Looney and Falta (2000, Figure 1-6).

Figure 5 Water retention curves for various soils as defined by Schaap and Leij (1998)

Figure 6 Capillary rise in a small diameter tube; reproduced from Looney and Falta (2000, Fig. 1-5)

Figure 7 Liquid inventories in Tank 41 before and after pumping for three optimal parameter settings (345" saltcake level)................................. 20

Figure 8 Schematic representation of interstitial liquid level across Tank $41 \ldots \ldots . .26$

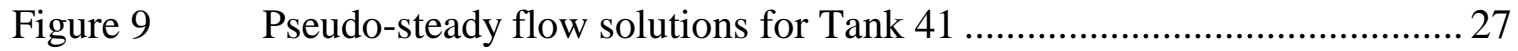

Figure $10 \quad$ Estimated drainage time starting from a mean tank level of 48 " ............. 28 
This page intentionally left blank 


\section{Introduction}

Under the Low Curie Salt Program, interstitial liquid is being drained from saltcake in Tank 41 to remove most of the Cs-137 activity. After the liquid content in saltcake approaches the residual saturation level, the tank will be re-flooded to a level 2" above the saltcake level. Then at least 30 " of saltcake will be dissolved off the top and disposed of as saltstone according to near-term plans. The program is contingent upon reducing residual liquid content, and thus residual Cs-137 content (Romanowski, 2002), to a sufficiently low level. High Level Waste (HLW) requested assistance from the Savannah River Technology Center (SRTC) in analyzing drain operations from 9/8/02 through 11/11/02 to better understand the interstitial liquid level profile across the tank, and the liquid saturation profile from tank bottom to top (TTR No. HLE-TTR-2003-057, Rev. 1).

\section{Tank 41 drawdown and well recovery data}

A hole of approximately $3 \mathrm{ft}$ in diameter was bored through Tank 41 saltcake by water jetting and dissolution to create a well. The well is centered approximately $6.5 \mathrm{ft}$ from the tank wall. Prior to draining, the saltcake level was at approximately $350 "$ and the liquid level at 357.17". A submersible pump was then used to draw supernate from the tank at a variable rate between $9 / 8 / 02$ and $9 / 22 / 02$, and then 10/11 through 11/11. The well drawdown curve, covering both phases of the overall drain operation, is shown in Figure 1. Net liquid removal volumes are compiled in Table 1.

For the purpose of performing mass balances, the average interstitial liquid level in Tank 41 is needed as opposed to the level at the well. Given sufficient time, the well level will recover to an equilibrium level equal to the average tank level during dynamic operations. Two recovery periods are sufficiently long to project equilibrium/average tank liquid level with reasonable accuracy. As indicated in Figure 1, the projected well recovery levels for these intervals are 260" and 160". The 260" equilibrium tank level was estimated from the well recovery curve plotted in semi-log form (Figure 2). Between 1 and 10 days the data exhibits a logarithmic trend (straight-line on semi-log plot). Supposing this trend continues out to 30 days based on engineering judgment, the well level is projected to reach approximately $260 "$. Taking this as the equilibrium level after pumping ceased, the tank liquid drawdown becomes 357" - 260" = 97". The 160" level is based on inspection of Figure 1 and engineering judgment. 


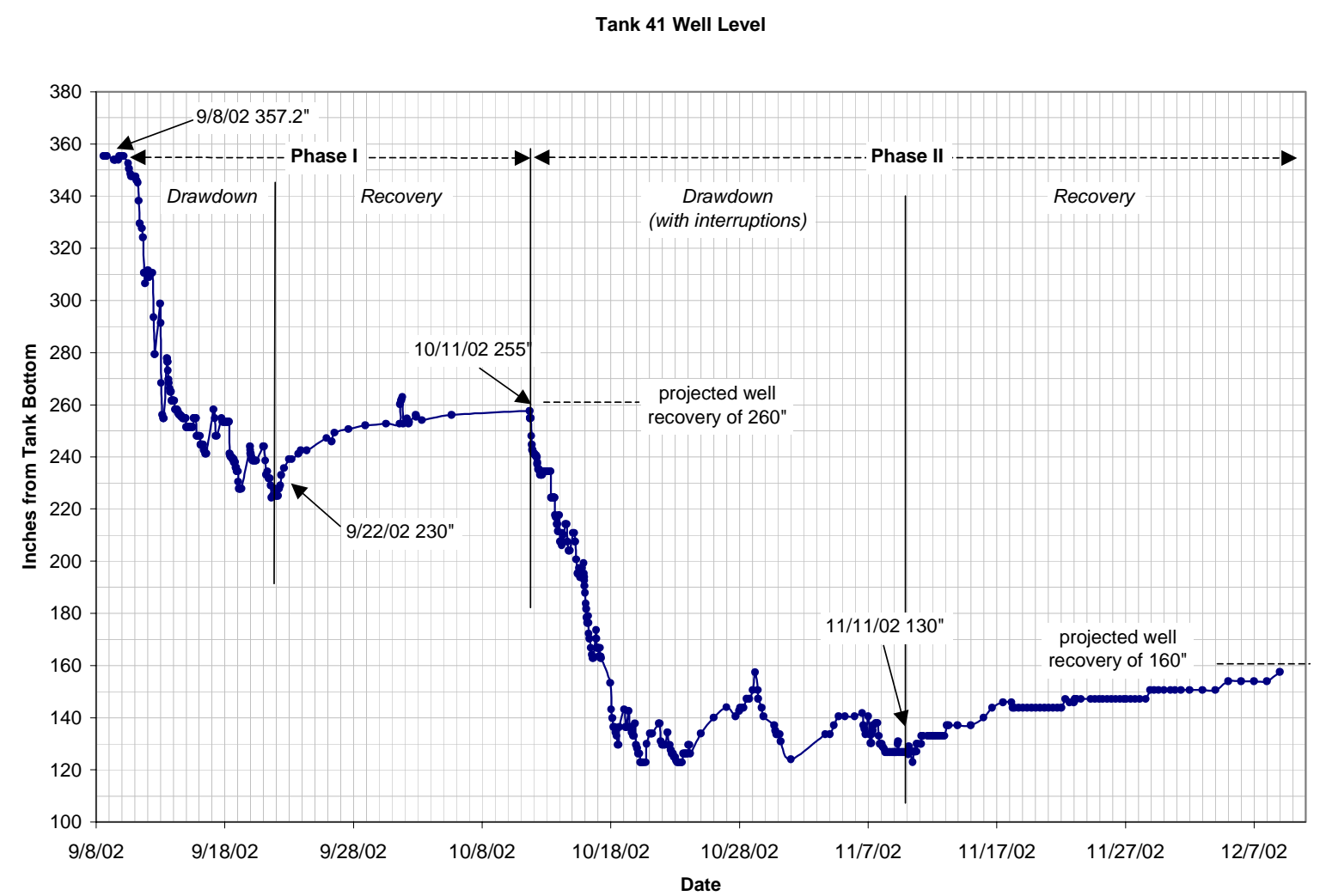

Figure 1. Well drawdown and recovery data for Tank 41 between 9/8/02 and $12 / 9 / 02$.

Table 1. Net liquid removal during Tank 41 drain operations from 9/8/02 through $12 / 9 / 02$.

\begin{tabular}{|cccccc|}
\hline Phase & Date range & $\begin{array}{c}\text { Range in } \\
\text { average tank } \\
\text { level }\end{array}$ & $\begin{array}{c}\text { Liquid } \\
\text { removed } \\
\text { (gal) }\end{array}$ & $\begin{array}{r}\text { Liquid } \\
\text { added } \\
\text { (gal) }\end{array}$ & $\begin{array}{c}\text { Net } \\
\text { removal } \\
\text { (gal) }\end{array}$ \\
\hline I & $9 / 8-10 / 11$ & $357.2 "$ - 260" & 71,800 & 3,596 & 68,204 \\
II & $10 / 11-12 / 9$ & 260" - 160" & 59,400 & 14,630 & 44,770 \\
I+II & $9 / 8-12 / 9$ & $357.2 "$ - 160" & 131,200 & 18,226 & 112,974 \\
\hline
\end{tabular}




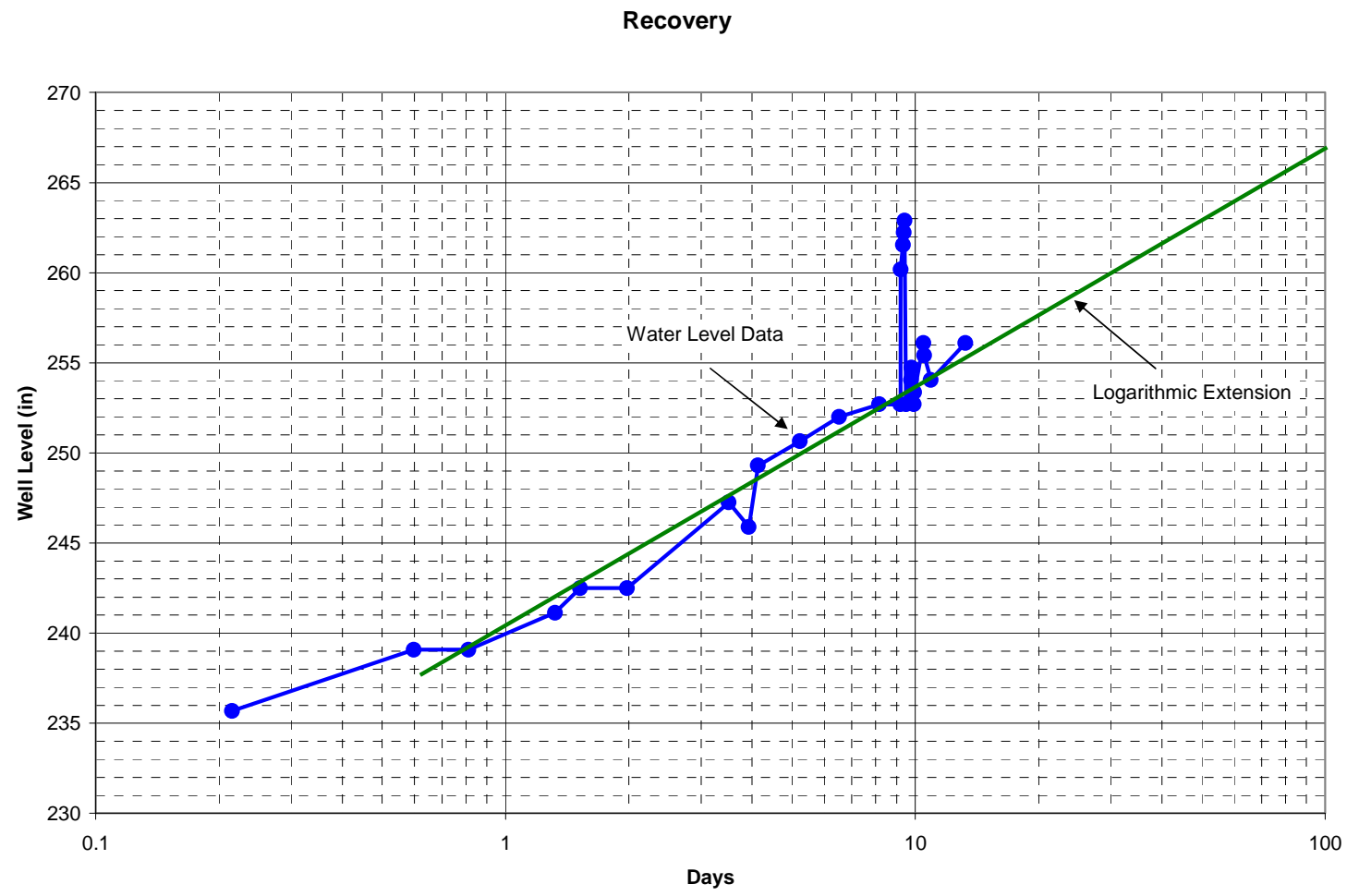

Figure 2. Well recovery curve with logarithmic forecast.

\section{Static gravity-equilibrium analysis of pre- and post-drain tank level}

Saltcake is comprised of salt crystals, and interstitial liquid and radiolytic gas. The gas content of submerged Tank 41 saltcake has been accurately estimated to be $10.5 \%$ as a fraction of total volume (Hester, 2001, p. 4). The liquid content of saltcake is less well known. Based on work by Fowler (1982) and Wiersma (1996), Hester (2002) roughly estimated total porosity at $42 \%$, or equivalently a liquid content of $31.5 \%$ for submerged saltcake. However, the drainable liquid content was based on simulated saltcake that contains no appreciable gas. Therefore, the total porosity should exclude the gas contribution and be closer to $31.5 \%$. Samples taken from Tank 41 have averaged about $42 \%$ porosity, and ranged from $30 \%$ to $49 \%$ (Pike et al., 2001; Pike, 2002). Hence the porosity of Tank 41 saltcake is uncertain. The liquid retention characteristics of saltcake under unsaturated conditions are equally uncertain.

Given uncertainties in total porosity and liquid retention characteristics of saltcake, many combinations of values could be assumed for these parameters. However, knowing preand post-drain tank levels and the volume of pumped liquid, a static mass balance can be used to constrain the combinations of total porosity and liquid retention values that 
saltcake could possibly take on. The method for doing so, and results for Tank 41 based on drain operations from 9/8/02 through 12/9/02, are presented below.

\section{Method}

The volume of interstitial supernate per unit thickness equals tank cross-sectional area times total porosity times liquid saturation:

$$
\frac{\Delta V}{\Delta z}=A(z) \cdot n \cdot S_{w}(z)
$$

Total porosity is the volume of saltcake voids divided by total volume ( $\left.n=V_{\text {void }} / V_{\text {total }}\right)$. Saturation is the liquid volume divided by void volume $\left(S_{w}=V_{\text {liquid }} / V_{\text {void }}\right)$. The product of total porosity and saturation is then the volume of liquid divided by total volume $\left(\theta_{w}=n \cdot S_{w}=V_{\text {void }} / V_{\text {total }} \cdot V_{\text {liquid }} / V_{\text {void }}=V_{\text {liquid }} / V_{\text {total }}\right)$, commonly termed "water content" in hydrology.

Note that both cross-sectional area and liquid saturation are assumed to vary with elevation. The liquid inventory of the entire tank is the summation of equation (1) from tank bottom to top:

$$
V=\sum_{b o t}^{t o p} A(z) \cdot n \cdot S_{w}(z) \cdot \Delta z
$$

For a tank drain operation, the change in inventory associated with the pre- and postoperation equilibrium or average tank liquid levels should equal the volume pumped.

$$
V_{\text {pumped }}=\Delta V
$$

The cross-sectional area of Tank 41 can be approximated as the area between the outer wall and center column ignoring cooling tubes and other hardware (Figure 3). Below the conical "funnel" portion of the center column, this area is about 3510 gal/in (Table 2). The total porosity and liquid retention properties of saltcake are not known with certainty. Lacking information to the contrary, total porosity averaged over a cross-section is assumed to be roughly constant with elevation. Under static conditions, saltcake liquid saturation as a function of elevation can be estimated directly from an appropriate liquid retention curve.

Liquid flow, whether under full or partial saturation conditions, is driven by hydraulic head variations. Hydraulic head is defined by 


$$
h=\frac{p}{\rho g}+z=\psi+z
$$

where $p$ is gage pressure, $\rho$ is liquid density, $g$ is gravitational acceleration, $z$ is elevation, and $\psi$ is pressure head. Under static conditions, i.e. after any flow transients have subsided, hydraulic head must be constant, and equal to the interstitial liquid level (the liquid level that would be measured in a well):

$$
h=\text { constant }=z_{W L}
$$

The latter is true because at the elevation of the liquid level in the well, the gage pressure is zero and the elevation is $z=z_{W L}$, thus $h=p / \rho g+z=0+z_{W L}$. While hydraulic head is constant under static conditions, the pressure head varies linearly with elevation as

$$
\psi(z)=h-z=z_{W L}-z
$$

Knowing the pressure head variation in the tank, the saturation profile can be determined from the liquid retention curve, a physical property of the porous medium:

$$
S_{w}=f c n(-\psi)
$$

The quantity $-\psi$ is sometimes referred to as "capillary suction head" and is positivevalued for saturations less than $100 \%$ in typical situations. Other terms used for the relationship indicated by equation (7) are "water retention curve", "capillary pressure curve", and "soil curve". Figure 4 illustrates some of the attributes and terminology associated with water retention curves. A very commonly used functional form for the liquid retention curve is (van Genuchten, 1980)

$$
\frac{S_{w}-S_{w r}}{1-S_{w r}}=\left[1+(-\alpha \psi)^{\beta}\right]^{-(1-1 / \beta)}
$$

where $S_{w r}$ (residual saturation), $\alpha$ and $\beta$ are medium-specific empirical constants determined from laboratory measurements of saturation and capillary suction head. Generic parameters for six soils were chosen as potential surrogates for saltcake (Table 3). The parameter settings are from Schaap and Leij (1998). The corresponding water retention curves for Sand, Loamy Sand, Sandy Loam, Loam, Silt Loam and Clay are shown in Figure 5.

Equation (8) implicitly assumes that liquid saturation is $100 \%\left(S_{w}=1\right)$ at (and below) the water table $(\psi=0)$. This is the normal situation for a porous media. Tank 41 saltcake is an exception because of radiolytic gas. Rather than voids being $100 \%$ liquid filled in submerged saltcake, gas bubbles occupy a significant fraction of total porosity. As stated 
previously, the gas content in Tank 41 saltcake is $10.5 \%$ on a bulk basis. If the total porosity were $42 \%$ following Hester (2002), the gas and liquid saturations would be $25 \%$ and $75 \%$ respectively, for example. Thus a modified version of equation (8) is required to deal with partial liquid saturation of submerged saltcake.

A simple and straight-forward modification to equation (8) is

$$
\frac{S_{w}-S_{w r}}{S_{w s}-S_{w r}}=\frac{S_{w} / S_{w s}-S_{w r} / S_{w s}}{1-S_{w r} / S_{w s}}=\frac{S_{w}{ }^{\prime}-S_{w r}{ }^{\prime}}{1-S_{w r}{ }^{\prime}}=\left[1+(-\alpha \psi)^{\beta}\right]^{-(1-1 / \beta)}
$$

where $S_{w s}$ is the liquid saturation for submerged saltcake. This modification amounts to lumping radiolytic gas with salt crystals as "solids" and redefining "voids" to be only that volume occupied by liquid in submerged saltcake. Then a new "total" porosity can be defined as $n^{\prime}=V_{w s} / V_{\text {total }}$ where $V_{w s}$ is liquid volume for submerged saltcake, and liquid saturation can be re-interpreted as liquid volume divided by liquid volume under submerged conditions, i.e. $S_{w}=V_{w} / V_{w s}$. In, mass balance, equation (2) and elsewhere, the product $n S_{w}$ can be replaced with $n^{\prime} S_{w}\left(n S_{w}=n^{\prime} S_{w}\right)$. In Table 3 and Figure 5, values for the liquid saturation would be used for the new pseudo-liquid saturation $S_{w}$ for Tank 41 saltcake.

Another issue is that the density and surface tension of Tank 41 supernate differ from water. Therefore supernate can be expected to exhibit a different liquid retention curve than water in the same porous medium. The differences that might be observed can be qualitatively estimated by considering capillary rise in a tube (Figure 6). The capillary rise, $h$, is given by

$$
h=\frac{2 \sigma}{\rho g r}
$$

where $\sigma$ is surface tension, $\rho$ is density, $g$ is gravitational acceleration, and $r$ is radius. For Tank 41 supernate compared to water

$$
\frac{\rho_{T k 41}}{\rho_{w}} \approx 1.5 \quad \frac{\sigma_{T k 41}}{\sigma_{w}} \approx 1.3
$$

(Sebastian Aleman, personal communication). Because these ratios are similar, the capillary rise for Tank 41 supernate would be similar to water. This suggests the curves shown in Figure 5 are reasonable candidates for supernate retention. 


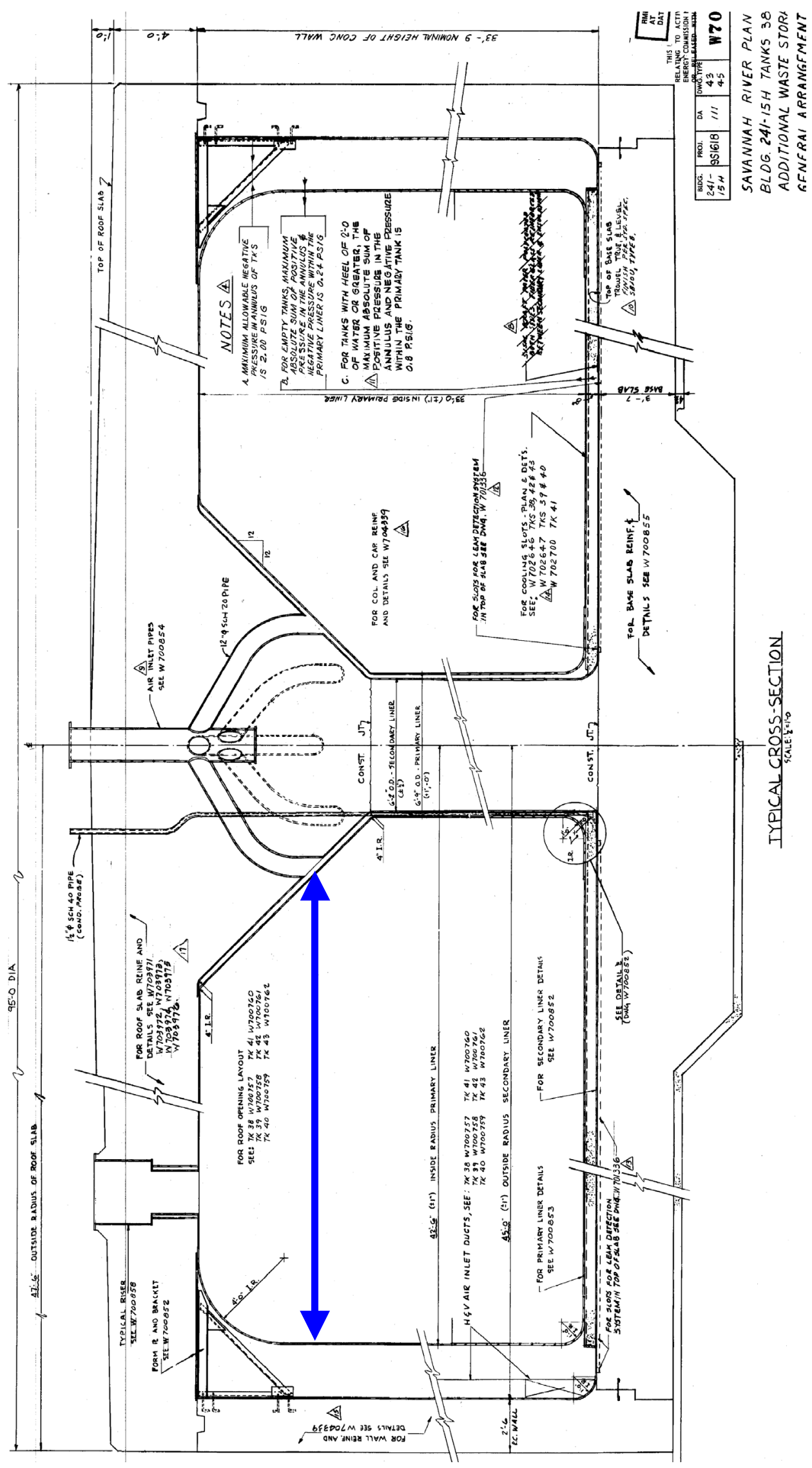

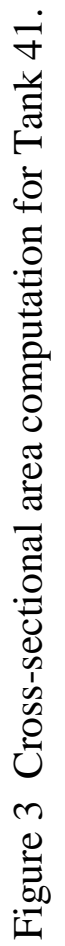


Table 2. Cross-sectional area of Tank 41 at various elevations.

\begin{tabular}{|c|c|c|c|c|c|c|c|}
\hline $\begin{array}{c}\text { Depth } \\
\mathrm{ft}\end{array}$ & $\begin{array}{c}\text { Elevation } \\
\mathrm{ft}\end{array}$ & $\begin{array}{c}\text { Outer } \\
\text { radius } \\
\mathrm{ft}\end{array}$ & $\begin{array}{c}\text { Inner } \\
\text { radius } \\
\mathrm{ft}\end{array}$ & $\begin{array}{c}\text { Xsec area } \\
\mathrm{ft}^{2}\end{array}$ & $\begin{array}{c}\text { Xsec area } \\
\mathrm{gal} / \mathrm{ft}\end{array}$ & $\begin{array}{c}\text { Xsec area } \\
\text { gal/in }\end{array}$ & $\begin{array}{c}\text { Elevation } \\
\text { in }\end{array}$ \\
\hline 0 & 34 & 42.5 & 11.7 & 5244 & 39231 & 3269 & 408 \\
\hline 1 & 33 & 42.5 & 10.7 & 5315 & 39758 & 3313 & 396 \\
\hline 2 & 32 & 42.5 & 9.7 & 5379 & 40237 & 3353 & 384 \\
\hline 3 & 31 & 42.5 & 8.7 & 5437 & 40669 & 3389 & 372 \\
\hline 4 & 30 & 42.5 & 7.7 & 5488 & 41055 & 3421 & 360 \\
\hline 5 & 29 & 42.5 & 6.7 & 5533 & 41393 & 3449 & 348 \\
\hline 6 & 28 & 42.5 & 5.7 & 5572 & 41685 & 3474 & 336 \\
\hline 7 & 27 & 42.5 & 4.7 & 5605 & 41929 & 3494 & 324 \\
\hline 8 & 26 & 42.5 & 3.7 & 5631 & 42126 & 3511 & 312 \\
\hline 9 & 25 & 42.5 & 3.4 & 5638 & 42177 & 3515 & 300 \\
\hline 10 & 24 & 42.5 & 3.4 & 5638 & 42177 & 3515 & 288 \\
\hline 11 & 23 & 42.5 & 3.4 & 5638 & 42177 & 3515 & 276 \\
\hline 12 & 22 & 42.5 & 3.4 & 5638 & 42177 & 3515 & 264 \\
\hline 13 & 21 & 42.5 & 3.4 & 5638 & 42177 & 3515 & 252 \\
\hline 14 & 20 & 42.5 & 3.4 & 5638 & 42177 & 3515 & 240 \\
\hline 15 & 19 & 42.5 & 3.4 & 5638 & 42177 & 3515 & 228 \\
\hline 16 & 18 & 42.5 & 3.4 & 5638 & 42177 & 3515 & 216 \\
\hline 17 & 17 & 42.5 & 3.4 & 5638 & 42177 & 3515 & 204 \\
\hline 18 & 16 & 42.5 & 3.4 & 5638 & 42177 & 3515 & 192 \\
\hline 19 & 15 & 42.5 & 3.4 & 5638 & 42177 & 3515 & 180 \\
\hline 20 & 14 & 42.5 & 3.4 & 5638 & 42177 & 3515 & 168 \\
\hline 21 & 13 & 42.5 & 3.4 & 5638 & 42177 & 3515 & 156 \\
\hline 22 & 12 & 42.5 & 3.4 & 5638 & 42177 & 3515 & 144 \\
\hline 23 & 11 & 42.5 & 3.4 & 5638 & 42177 & 3515 & 132 \\
\hline 24 & 10 & 42.5 & 3.4 & 5638 & 42177 & 3515 & 120 \\
\hline 25 & 9 & 42.5 & 3.4 & 5638 & 42177 & 3515 & 108 \\
\hline 26 & 8 & 42.5 & 3.4 & 5638 & 42177 & 3515 & 96 \\
\hline 27 & 7 & 42.5 & 3.4 & 5638 & 42177 & 3515 & 84 \\
\hline 28 & 6 & 42.5 & 3.4 & 5638 & 42177 & 3515 & 72 \\
\hline 29 & 5 & 42.5 & 3.4 & 5638 & 42177 & 3515 & 60 \\
\hline 30 & 4 & 42.5 & 3.4 & 5638 & 42177 & 3515 & 48 \\
\hline 31 & 3 & 42.5 & 3.4 & 5638 & 42177 & 3515 & 36 \\
\hline 32 & 2 & 42.5 & 3.4 & 5638 & 42177 & 3515 & 24 \\
\hline 33 & 1 & 42.5 & 3.4 & 5638 & 42177 & 3515 & 12 \\
\hline 34 & 0 & 42.5 & 3.4 & 5638 & 42177 & 3515 & 0 \\
\hline
\end{tabular}




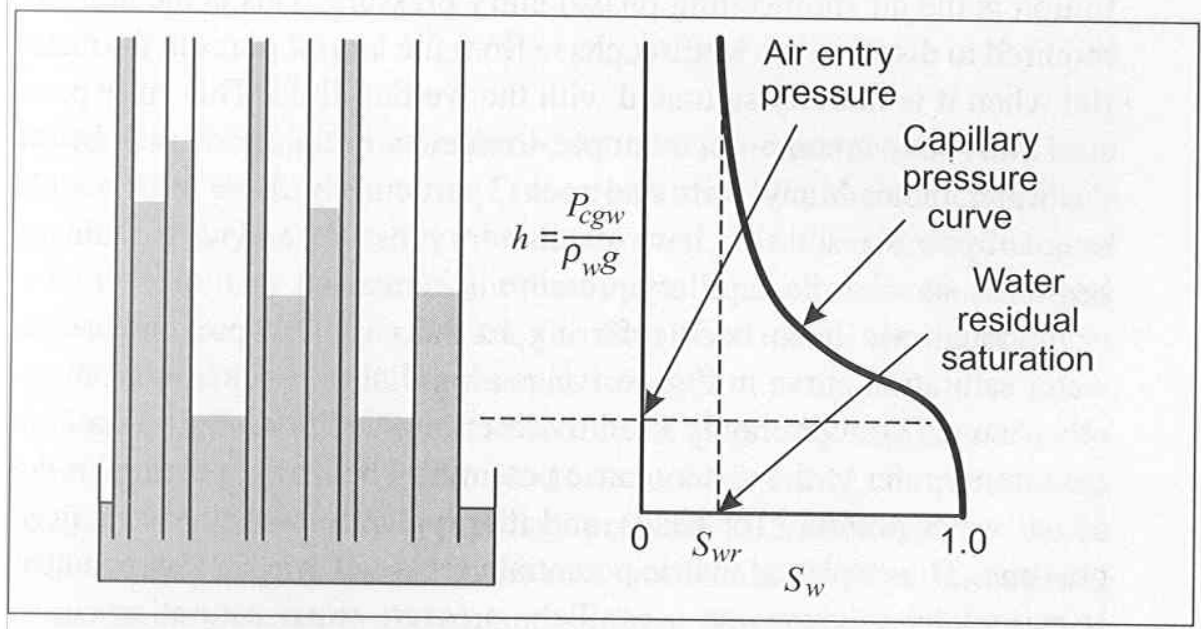

Figure 4 Water retention curve corresponding to varying capillary rise with varying pore sizes in a porous medium; reproduced from Looney and Falta (2000, Figure 1-6).

Table 3 van Genuchten (1980) parameters for various soils as defined by Schaap and Leij (1998).

\begin{tabular}{|lcccccc|}
\hline $\begin{array}{c}\text { van } \\
\begin{array}{c}\text { Genuchten } \\
\text { (1980) }\end{array} \\
\text { parameter }\end{array}$ & Sand & $\begin{array}{c}\text { Loamy } \\
\text { sand }\end{array}$ & $\begin{array}{c}\text { Sandy } \\
\text { Loam }\end{array}$ & Loam & Silt Loam & Clay \\
\hline $\mathrm{S}_{\mathrm{wr}}$ & 0.141 & 0.126 & 0.101 & 0.153 & 0.148 & 0.214 \\
$\alpha, \mathrm{cm}^{-1}$ & 0.0355 & 0.0347 & 0.0269 & 0.0112 & 0.0050 & 0.0151 \\
$\beta$ & 3.16 & 1.74 & 1.45 & 1.48 & 1.66 & 1.26 \\
\hline
\end{tabular}




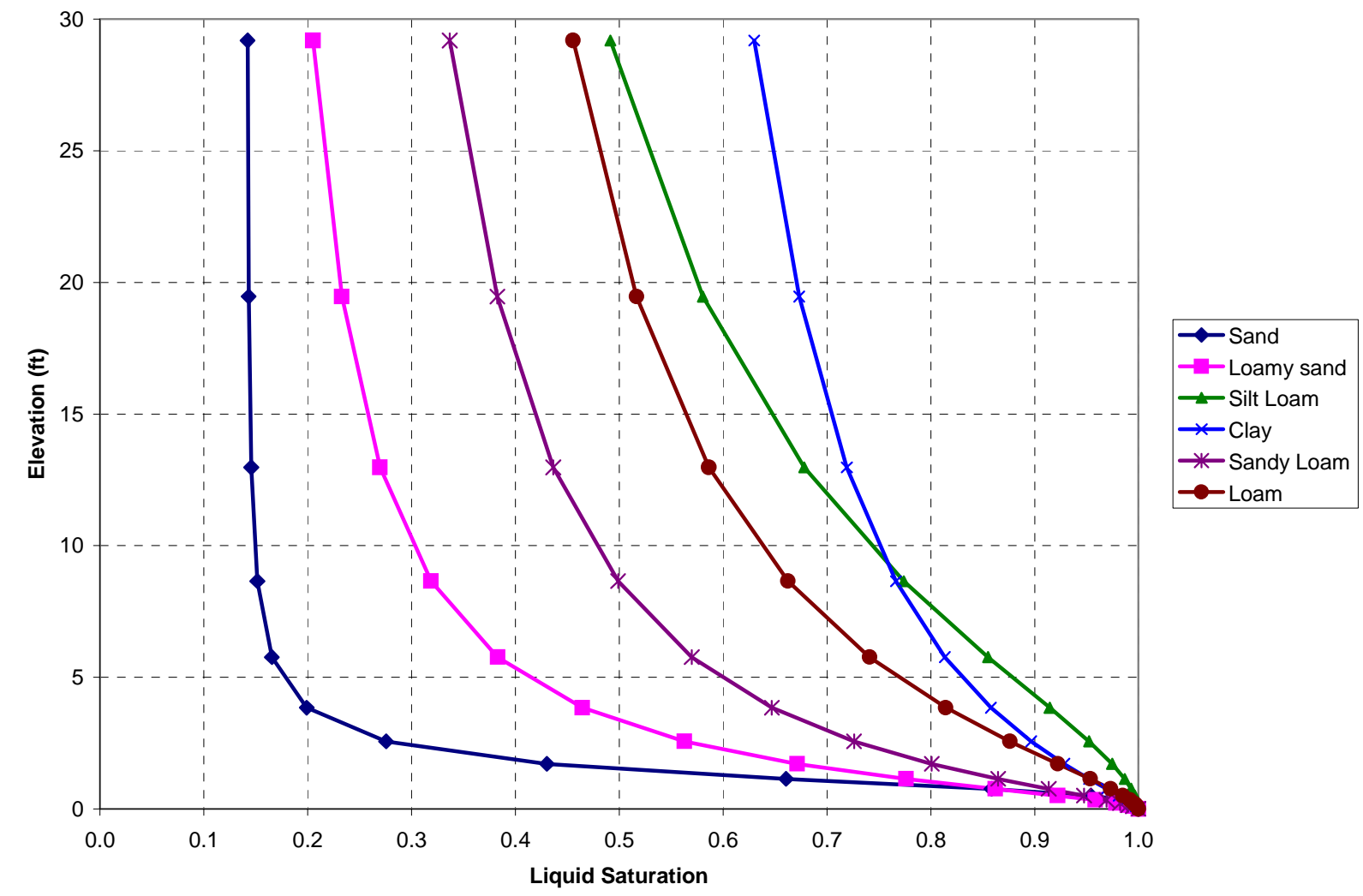

Figure 5 Water retention curves for various soils as defined by Schaap and Leij (1998).

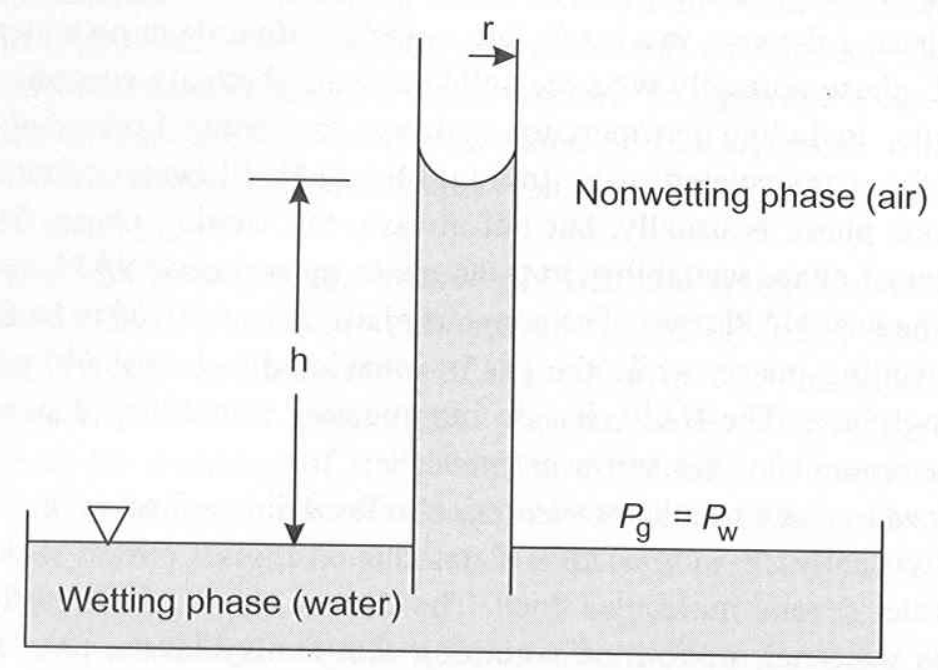

Figure 6. Capillary rise in a small diameter tube; reproduced from Looney and Falta (2000, Fig. 1-5). 


\section{Results of parametric study}

Combinations of total porosity and liquid retention settings that are consistent with the saltcake dewatering operation in Tank 41 can be identified through a parametric study. In this section, the term "pseudo total porosity" refers to the fraction of total volume occupied by liquid in submerged saltcake, i.e. $n^{\prime}$, as opposed to the true porosity $n$. In other words, "pseudo total porosity" refers to the initial liquid content in Tank 41 saltcake. Likewise, "pseudo saturation" is the volume of liquid divided by the volume of liquid in submerged saltcake, i.e. $S_{w r}$. These definitions are used to deal with the presence of radiolytic gas as discussed above.

Consistent combinations are those for which the computed inventory change matches the actual net liquid removal, i.e. satisfy equations (1) through (3). An example inventory change (mass balance) calculation for $10 \%$ initial water content $\left(n^{\prime}=0.1\right)$, a "Sand" water retention curve, a 350" saltcake level, and a liquid level change from 357.2" to 260" is shown in Table 4. For this case the modeled inventory change is $34 \%$ lower than the actual volume of liquid removed. Assuming the gas content is $10.5 \%$, the true void fraction in this example becomes $20.5 \%$.

Table 5 shows the results for the reported saltcake level of 350", pseudo total porosity between 10 and $40 \%$, and liquid retention characteristics ranging from "Sand" to "Clay" (Figure 5). Combinations of porosity and liquid retention curve that produce agreement between the modeled inventory change and net volume pumped are highlighted. Note that the optimal values differ between the Phases I and II of drain operations. A potential explanation is that saltcake properties differ between the upper and middle portions of Tank 41.

Alternatively, the drawdown data plotted in Figure 1 suggest the average saltcake level may be closer to $345 "$, where the curve abruptly declines. This is inferred to be a result of the liquid level falling below the saltcake level. Table 6 shows results analogous to Table 3 , but with the saltcake level set to $345 "$ ". Also, the resolution of the porosity variations has been increased. The optimal parameter settings show closer overlap between the two drainage phases, suggesting more uniformity in the saltcake than implied by Table 5 . Figure 7 shows three of the optimal parameter settings from Table 6. Note that the difference (area) between the pre- and post-drain curves, representing the reduction in liquid inventory, is the same. However, the residual liquid content varies significantly between cases.

The parameter values in Tables 5 and 6 are values of pseudo total porosity and residual liquid saturation, $n^{\prime}$ and $S_{w r}$. Knowing the gas content of submerged saltcake $\theta_{g}=V_{\text {gas }} / V_{\text {total }}$, these can be converted into true porosity (void fraction) $n$ and 
saturation $S_{w r}{ }^{\prime}$ as follows. True porosity is the sum of the water and gas contents for submerged saltcake:

$$
n=\frac{V_{\text {void }}}{V_{\text {total }}}=\frac{V_{w s}}{V_{\text {total }}}+\frac{V_{\text {gas }}}{V_{\text {total }}}=\theta_{w s}+\theta_{g}=n^{\prime}+\theta_{g}
$$

Noting that water content can be expressed as

$$
n^{\prime} S_{w}{ }^{\prime}=\frac{V_{w s}}{V_{\text {total }}} \frac{V_{\text {liquid }}}{V_{w s}}=\theta_{w}=\frac{V_{\text {void }}}{V_{\text {total }}} \frac{V_{\text {liquid }}}{V_{\text {void }}}=n S_{w}
$$

true liquid saturation can be then be computed from

$$
S_{w}=\frac{n^{\prime}}{n} S_{w}^{\prime}
$$

As an example from Table 6, 30\% pseudo total porosity and $46 \%$ pseudo residual saturation correspond to a true porosity of

$$
n=n^{\prime}+\theta_{g}=0.3+0.105=0.405=40 \%
$$

and a true liquid saturation of

$$
S_{w r}=\frac{n^{\prime}}{n} S_{w r}^{\prime}=\frac{0.3}{0.405} 0.46=0.34=34 \%
$$

for a gas content of $10.5 \%$. Both sets of numbers correspond to the residual water content of nearly $14 \%(0.3 \times 0.46=0.405 \times 0.34=0.138)$ for this example.

\section{Simplified analysis of Phase II drainage}

For the second phase of drainage operations (Figure 1), both the pre- and post-liquid levels have a capillary fringe and the cross-sectional area is constant. Under these conditions, the mass balance can essentially be simplified to

$$
\Delta V=A \cdot n^{\prime} \cdot\left(1-S_{w r}^{\prime}\right) \cdot\left(z_{\text {initial }}-z_{\text {final }}\right)
$$

Defining a drainage porosity (drainable water content) as

$$
\theta_{d}=n^{\prime} \cdot\left(1-S_{w r}^{\prime}\right)=n-\theta_{g}-\theta_{w r}
$$

produces 


$$
\Delta V=A \cdot \theta_{d} \cdot\left(z_{\text {initial }}-z_{\text {final }}\right)
$$

or conversely

$$
\theta_{d}=\frac{\Delta V}{A \cdot\left(z_{\text {initial }}-z_{\text {final }}\right)}
$$

Of interest to the Low Curie Salt Program is residual water content

$$
\theta_{r}=n^{\prime} \cdot S_{w r}^{\prime}=n \cdot S_{w r}
$$

Note that the sum of drainage and residual water content is pseudo total porosity:

$$
n^{\prime}=\theta_{r}+\theta_{d}
$$

or equivalently true porosity is

$$
n=\theta_{g}+\theta_{r}+\theta_{d}
$$

As shown in Table 7, drainage porosity is estimated to be approximately $13 \%$ for the second phase of Tank 41 operations. Because Phase II affected the middle portion of the tank, this estimates applies to that region of the tank.

Also shown in Table 7 are the residual water contents corresponding to a range of pseudo total porosity values. Knowledge of the porosity of saltcake, expressed as $n$ or $n^{\prime}$, would be needed to determine which residual liquid content value is appropriate. If $\theta_{d}$ and $n^{\prime}$ are known then

$$
S_{w r}^{\prime}=1-\frac{\theta_{d}}{n^{\prime}}
$$

and residual liquid content can be directly computed as $n^{\prime} \cdot S_{w r}{ }^{\prime}$. Alternatively, if $\theta_{d}$ and $S_{w r}$ are known then

$$
n^{\prime}=\frac{\theta_{d}}{\left(1-S_{w r}^{\prime}\right)}
$$

and residual liquid content can again be directly computed as $n^{\prime} \cdot S_{w r}{ }^{\prime}$.

Drainage porosity can also be estimated directly from Tables 5 and 6 for both Phase I and II operations. Shown in Table 8 are optimal combinations of porosity and residual saturation values from Tables 5 and 6 . In some cases, interpolated values are used. For 
Phase II and the middle portion of the tank (260" to $160 ")$, the drainage porosity averages $17.5 \%$. This result is somewhat larger than the $13 \%$ estimated from the simplified analysis above. This is probably because the calculation in Table 8 assumes the dewatered saltcake has reached residual saturation. Most likely the saltcake had not completely drained when the level was at 160" and/or residual conditions had not been reached at the top of the saltcake when the level was at 260". Either situation would bias the simplified analysis towards a lower estimate, e.g. $13 \%$ versus $17.5 \%$. Hence, $13 \%$ would likely be a lower bound on drainage porosity, while $18 \%$ would likely be an optimistic or upper bound. A sensitivity analysis involving Table 7 suggests a best-estimate slightly higher than $13 \%$. For example, if the well level is assumed to eventually recovery to 168 " in Phase II due to slow additional drainage, the drainage porosity estimate becomes $14 \%$.

The drainage porosity estimates for Phase I and the upper portion of the tank vary strongly with assumed saltcake level (22\% for 350" saltcake versus $16 \%$ for 345 " saltcake level). The uncertainty in these estimates precludes any conclusion on whether the saltcake physical composition varies between the upper and middle portions of the tank. If the saltcake is believed to be relatively uniform between the upper and middle portions of the tank, then the Phase II estimates are preferred because they are more certain.

Table 9 shows various non-unique combinations of initial and residual water content that produce a drainage porosity of $14 \%$. Additional information is needed to narrow the possibilities. As stated previously, data from Fowler (1982), Wiersma (1996), Pike et al., (2001) and Pike (2002) suggest a total porosity of $42 \%$ and an initial liquid content of $31.5 \%$. If this estimate is accepted, then the highlighted rows in Table 9 define the characteristics of Tank 41 saltcake. Note that the residual liquid content is $16 \%$. 
Table 4 Mass balance results for $10 \%$ initial water content, "Sand" water retention, and a 350" saltcake level.

\begin{tabular}{|c|}
\multicolumn{1}{c|}{ Summary } \\
\hline case 1 \\
\hline 357.17 z (in) \\
147109 Tank inventory (gal) \\
$260 \mathrm{z}$ (in) \\
102057 Tank inventory (gal) \\
45052 Inventory change (gal) \\
68204 Target (gal) \\
-23152 Difference (gal) \\
$-34 \%$ Difference (\%) \\
\hline
\end{tabular}

Detail for 357" level

\begin{tabular}{|c|c|c|c|c|c|c|c|c|c|c|c|c|c|c|c|}
\hline $\begin{array}{c}\text { Depth } \\
\mathrm{ft}\end{array}$ & $\begin{array}{c}\text { Elevation } \\
\mathrm{ft}\end{array}$ & $\begin{array}{c}\text { Outer } \\
\text { radius } \\
\mathrm{ft}\end{array}$ & $\begin{array}{c}\text { Inner } \\
\text { radius } \\
\mathrm{ft}\end{array}$ & $\begin{array}{c}X s e c \text { area } \\
\mathrm{ft}^{2}\end{array}$ & $\begin{array}{c}X s e c \text { area } \\
\text { gal/ft }\end{array}$ & $\begin{array}{c}\text { Xsec area } \\
\text { gal/in }\end{array}$ & Porosity & $\begin{array}{c}\text { Water } \\
\text { saturation }\end{array}$ & $\begin{array}{c}\text { Water } \\
\text { content }\end{array}$ & $\begin{array}{c}\text { Water } \\
\text { volume } \\
\text { per unit z } \\
\text { gal/ft }\end{array}$ & $\begin{array}{c}\text { Water } \\
\text { volume per } \\
\text { increment } \\
\text { gal } \\
\end{array}$ & $\begin{array}{c}\text { Cumulative } \\
\text { volume } \\
\text { gal }\end{array}$ & $\begin{array}{c}\text { Elevation } \\
\text { in }\end{array}$ & 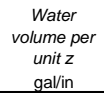 & $x$ for plotting \\
\hline & 34.00 & 42.5 & 11.70 & 5244 & 39231 & 3269 & 1 & 0.000 & 0.000 & 0 & 0 & 147109 & 408 & 0 & $\overline{0}$ \\
\hline 0.08 & 33.92 & 42.5 & 11.62 & 5251 & 39277 & 3273 & 1 & 0.000 & 0.000 & 0 & 0 & 147109 & 407 & 0 & 20000 \\
\hline 0.17 & 33.83 & 42.5 & 11.53 & 5257 & 39322 & 3277 & 1 & 0.000 & 0.000 & 0 & 0 & 147109 & 406 & 0 & \\
\hline 4.00 & 30.00 & 42.5 & 7.70 & 5488 & 41055 & 3421 & 1 & 0.000 & 0.000 & 0 & 0 & 147109 & 360 & 0 & \\
\hline 4.08 & 29.92 & 42.5 & 7.62 & 5492 & 41085 & 3424 & 1 & 0.000 & 0.000 & 0 & 0 & 147109 & 359 & 0 & \\
\hline 4.17 & 29.83 & 42.5 & 7.53 & 5496 & 41115 & 3426 & 1 & 0.000 & 0.000 & 0 & 1714 & 147109 & 358 & 0 & \\
\hline 4.25 & 29.75 & 42.5 & 7.45 & 5500 & 41144 & 3429 & 1 & 1.000 & 1.000 & 41144 & 3430 & 145395 & 357 & 3429 & \\
\hline 4.33 & 29.67 & 42.5 & 7.37 & 5504 & 41173 & 3431 & 1 & 1.000 & 1.000 & 41173 & 3432 & 141965 & 356 & 3431 & \\
\hline 4.42 & 29.58 & 42.5 & 7.28 & 5508 & 41202 & 3433 & 1 & 1.000 & 1.000 & 41202 & 3435 & 138532 & 355 & 3433 & \\
\hline & & & & & & & & $\vdots$ & & & & & & & \\
\hline 4.58 & 29.42 & 42.5 & 7.12 & 5515 & 41258 & 3438 & 1 & 1.000 & 1.000 & 41258 & 3439 & 131661 & 353 & 3438 & \\
\hline 4.67 & 29.33 & 42.5 & 7.03 & 5519 & 41286 & 3440 & 1 & 1.000 & 1.000 & 41286 & 3442 & 128221 & 352 & 3440 & \\
\hline 4.75 & 29.25 & 42.5 & 6.95 & 5523 & 41313 & 3443 & 1 & 1.000 & 1.000 & 41313 & 1894 & 124780 & 351 & 3443 & \\
\hline 4.83 & 29.17 & 42.5 & 6.87 & 5526 & 41340 & 3445 & 0.1 & 1.000 & 0.100 & 4134 & 345 & 122886 & 350 & 345 & \\
\hline 4.92 & 29.08 & 42.5 & 6.78 & 5530 & 41367 & 3447 & 0.1 & 1.000 & 0.100 & 4137 & 345 & 122542 & 349 & 345 & \\
\hline 5.00 & 29.00 & 42.5 & 6.70 & 5533 & 41393 & 3449 & 0.1 & 1.000 & 0.100 & 4139 & 345 & 122197 & 348 & 345 & \\
\hline 33.83 & 0.17 & 42.5 & 3.40 & 5638 & 42177 & 3515 & 0.1 & 1.000 & 0.100 & 4218 & 351 & 703 & 2 & 351 & \\
\hline 33.92 & 0.08 & 42.5 & 3.40 & 5638 & 42177 & 3515 & 0.1 & 1.000 & 0.100 & 4218 & 351 & 351 & 1 & 351 & \\
\hline 34.00 & 0.00 & 42.5 & 3.40 & 5638 & 42177 & 3515 & 0.1 & 1.000 & 0.100 & 4218 & 0 & 0 & 0 & 351 & \\
\hline
\end{tabular}

Detail for 260" level

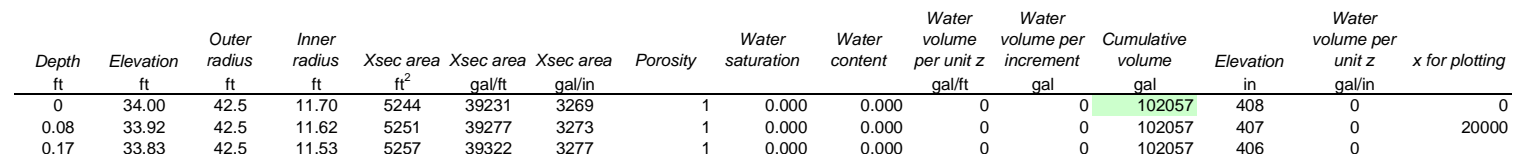

\begin{tabular}{|c|c|c|c|c|c|c|c|c|c|c|c|c|c|c|}
\hline 4.58 & 29.42 & 42.5 & 7.12 & 5515 & 41258 & 3438 & 1 & 0.000 & 0.000 & 0 & 0 & 102057 & 353 & 0 \\
\hline 4.67 & 29.33 & 42.5 & 7.03 & 5519 & 41286 & 3440 & 1 & 0.000 & 0.000 & 0 & 0 & 102057 & 352 & 0 \\
\hline 4.75 & 29.25 & 42.5 & 6.95 & 5523 & 41313 & 3443 & 1 & 0.000 & 0.000 & 0 & 27 & 102057 & 351 & 0 \\
\hline 4.83 & 29.17 & 42.5 & 6.87 & 5526 & 41340 & 3445 & 0.1 & 0.155 & 0.016 & 641 & 54 & 102030 & 350 & 53 \\
\hline 4.92 & 29.08 & 42.5 & 6.78 & 5530 & 41367 & 3447 & 0.1 & 0.155 & 0.016 & 643 & 54 & 101977 & 349 & 54 \\
\hline \multirow[t]{2}{*}{5.00} & 29.00 & 42.5 & 6.70 & 5533 & 41393 & 3449 & 0.1 & 0.156 & 0.016 & 645 & 54 & 101923 & 348 & 54 \\
\hline & & & & & & & & : & & & & & & \\
\hline 11.92 & 22.08 & 42.5 & 3.40 & 5638 & 42177 & 3515 & 0.1 & 0.974 & 0.097 & 4110 & 345 & 93128 & 265 & 342 \\
\hline 12.00 & 22.00 & 42.5 & 3.40 & 5638 & 42177 & 3515 & 0.1 & 0.987 & 0.099 & 4163 & 348 & 92784 & 264 & 347 \\
\hline 12.08 & 21.92 & 42.5 & 3.40 & 5638 & 42177 & 3515 & 0.1 & 0.995 & 0.099 & 4196 & 350 & 92435 & 263 & 350 \\
\hline 12.17 & 21.83 & 42.5 & 3.40 & 5638 & 42177 & 3515 & 0.1 & 0.999 & 0.100 & 4211 & 351 & 92085 & 262 & 351 \\
\hline 12.25 & 21.75 & 42.5 & 3.40 & 5638 & 42177 & 3515 & 0.1 & 1.000 & 0.100 & 4217 & 351 & 91734 & 261 & 351 \\
\hline \multirow[t]{2}{*}{12.33} & 21.67 & 42.5 & 3.40 & 5638 & 42177 & 3515 & 0.1 & 1.000 & 0.100 & 4218 & 351 & 91383 & 260 & 351 \\
\hline & & & & & & & & : & & & & & & \\
\hline 33.83 & 0.17 & 42.5 & 3.40 & 5638 & 42177 & 3515 & 0.1 & 1.000 & 0.100 & 4218 & 351 & 703 & 2 & 351 \\
\hline 33.92 & 0.08 & 42.5 & 3.40 & 5638 & 42177 & 3515 & 0.1 & 1.000 & 0.100 & 4218 & 351 & 351 & 1 & 351 \\
\hline 34.00 & 0.00 & 42.5 & 3.40 & 5638 & 42177 & 3515 & 0.1 & 1.000 & 0.100 & 4218 & 0 & 0 & 0 & 351 \\
\hline
\end{tabular}


Table 5 Results of total porosity/water retention parameter study for 350" saltcake level; table shows the percentage deviation between the modeled liquid inventory change and the actual net volume of liquid removed from Tank 41.

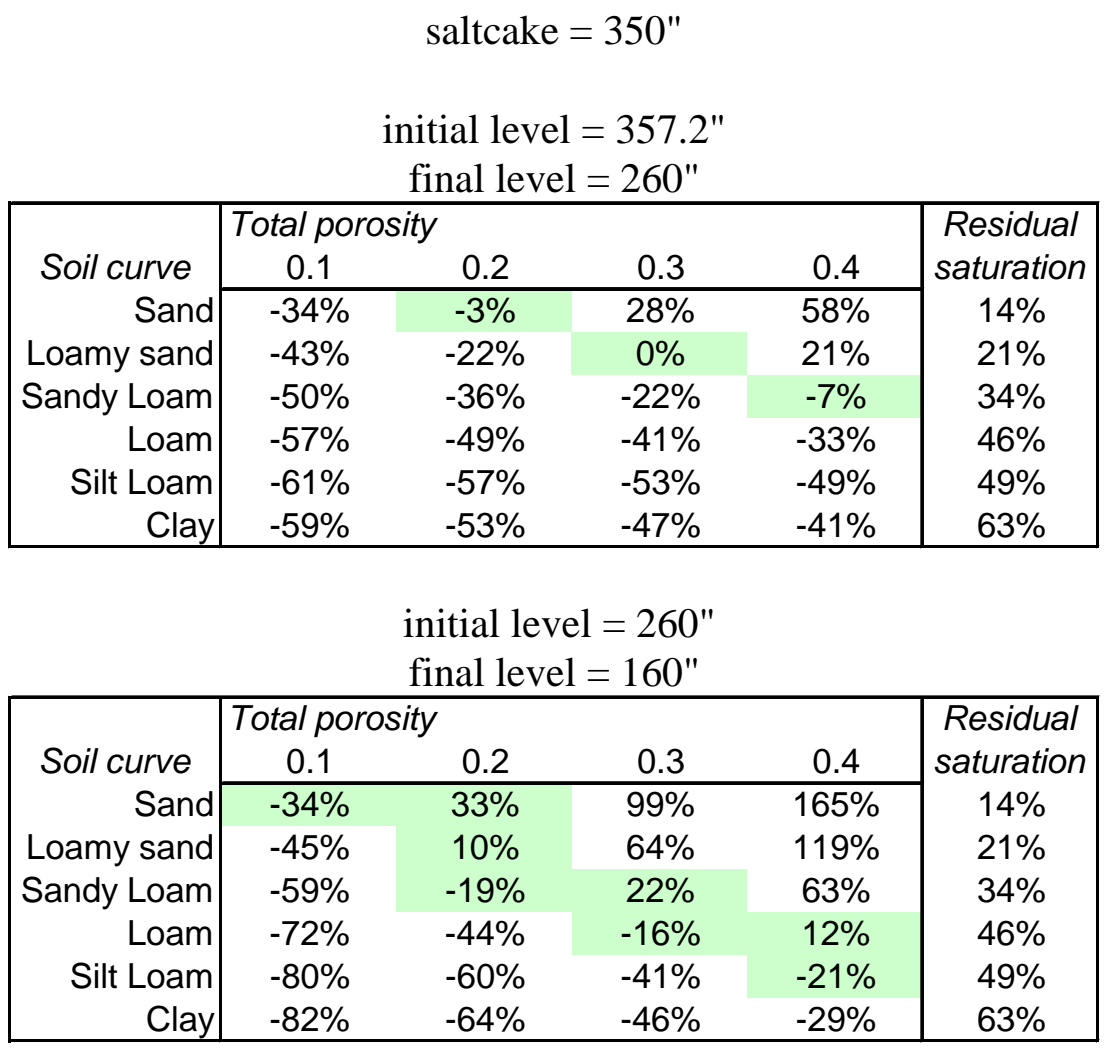


Table 6 Results of total porosity/water retention parameter study for a 345" saltcake level; table shows the percentage deviation between the modeled liquid inventory change and the actual net volume of liquid removed from Tank 41.

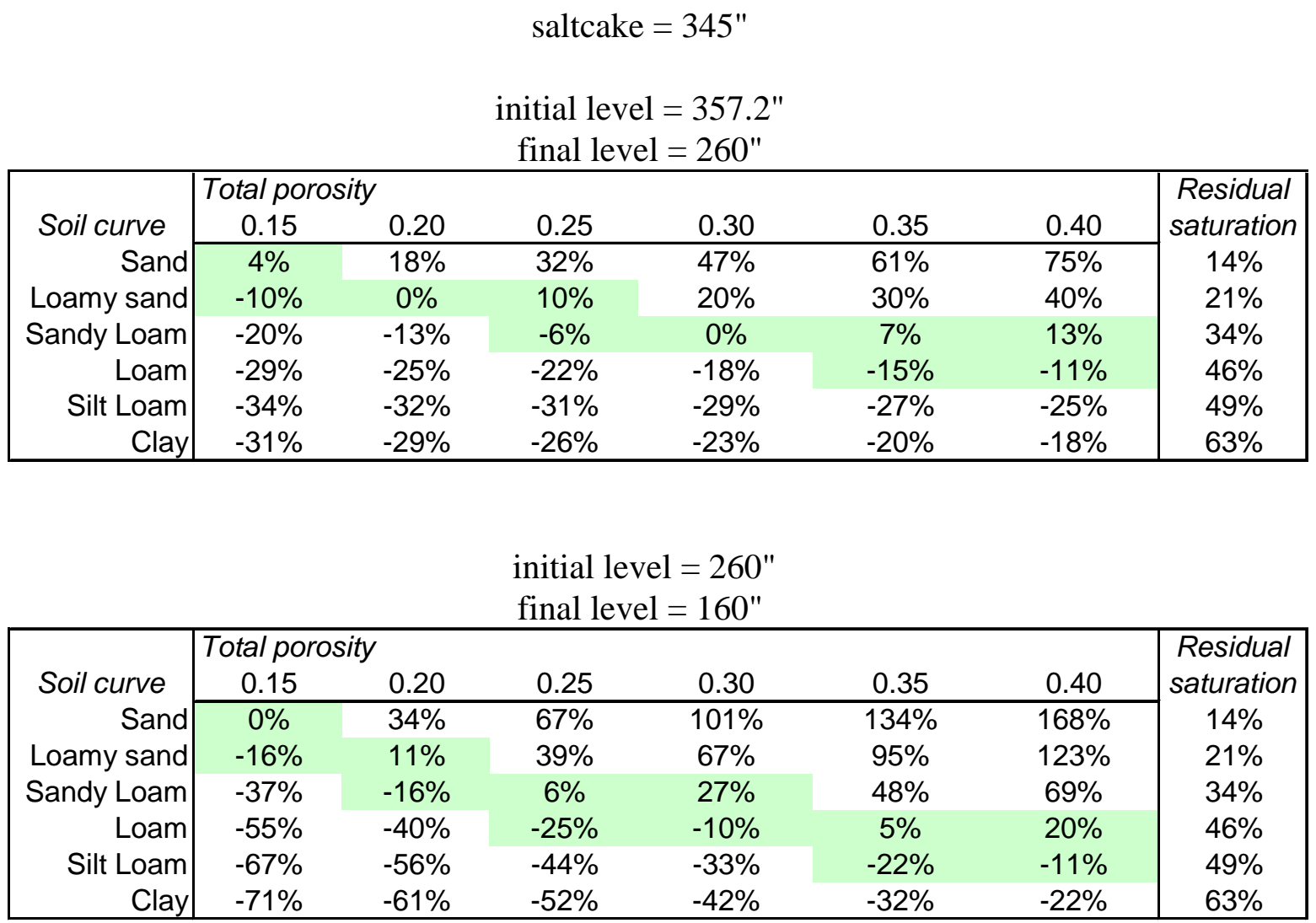


Table 7 Drainage porosity estimate based in Phase II of Tank 41 drain operations.

\begin{tabular}{|c|c|c|c|c|}
\hline $\begin{array}{r}44770 \\
260 \\
160 \\
100 \\
3510 \\
12.8 \%\end{array}$ & $\begin{array}{l}\text { Q (gal) } \\
\text { before (in } \\
\text { after (in) } \\
z \text { (in) } \\
(\text { (gal/in) } \\
\left(1-S_{r}\right)\end{array}$ & & & \\
\hline $\begin{array}{l}\text { drainable } \\
\text { liquid } \\
\text { fraction of } \\
\text { total } \\
\text { volume } \\
\theta\left(1-S_{r}\right)\end{array}$ & $\begin{array}{c}\text { void } \\
\text { fraction/ } \\
\text { total } \\
\text { porosity } \\
\theta\end{array}$ & $\begin{array}{c}\text { drainable } \\
\text { saturation } \\
1-S_{r}\end{array}$ & $\begin{array}{c}\text { residual } \\
\text { saturation } \\
\mathrm{S}_{\mathrm{r}}\end{array}$ & $\begin{array}{l}\text { residual } \\
\text { liquid } \\
\text { fraction of } \\
\text { total } \\
\text { volume } \\
\theta S_{r}\end{array}$ \\
\hline 0.128 & 0.16 & 0.80 & 0.20 & 0.032 \\
\hline 0.128 & 0.18 & 0.71 & 0.29 & 0.052 \\
\hline 0.128 & 0.20 & 0.64 & 0.36 & 0.072 \\
\hline 0.128 & 0.22 & 0.58 & 0.42 & 0.092 \\
\hline 0.128 & 0.24 & 0.53 & 0.47 & 0.112 \\
\hline 0.128 & 0.26 & 0.49 & 0.51 & 0.132 \\
\hline 0.128 & 0.28 & 0.46 & 0.54 & 0.152 \\
\hline 0.128 & 0.30 & 0.43 & 0.57 & 0.172 \\
\hline 0.128 & 0.32 & 0.40 & 0.60 & 0.192 \\
\hline 0.128 & 0.34 & 0.38 & 0.62 & 0.212 \\
\hline 0.128 & 0.36 & 0.35 & 0.65 & 0.232 \\
\hline 0.128 & 0.38 & 0.34 & 0.66 & 0.252 \\
\hline 0.128 & 0.40 & 0.32 & 0.68 & 0.272 \\
\hline 0.128 & 0.42 & 0.30 & 0.70 & 0.292 \\
\hline 0.128 & 0.44 & 0.29 & 0.71 & 0.312 \\
\hline 0.128 & 0.46 & 0.28 & 0.72 & 0.332 \\
\hline
\end{tabular}


Table 8 Drainage porosity estimates based on optimal results from parametric study summarized by Tables 5 and 6 .

Level change from $357.2 "$ to $260 "$

\begin{tabular}{|ccccccl|}
\hline $\begin{array}{c}\text { Saltcake } \\
\text { level }\end{array}$ & $\begin{array}{c}\text { void } \\
\text { fraction/ } \\
\text { total porosity } \\
\text { (in) }\end{array}$ & $\begin{array}{c}\text { residual } \\
\text { saturation }\end{array}$ & $\begin{array}{c}\text { drainable } \\
\text { liquid }\end{array}$ & $\begin{array}{c}\text { residual } \\
\text { liquid } \\
\text { draturation } \\
\text { saction of }\end{array}$ & \\
\hline 350 & 0.20 & 0.14 & 0.86 & 0.17 & 0.03 & Table 5 \\
fraction of & total volume & total volume & Comments \\
350 & 0.30 & 0.21 & 0.79 & 0.24 & 0.06 & Table 5 \\
350 & 0.40 & 0.34 & 0.66 & 0.26 & 0.14 & Table 5 \\
350 & & & & $\mathbf{0 . 2 2}$ & & average \\
\hline 345 & 0.15 & 0.14 & 0.86 & 0.13 & 0.02 & Table 6 \\
345 & 0.20 & 0.21 & 0.79 & 0.16 & 0.04 & Table 6 \\
345 & 0.25 & 0.34 & 0.66 & 0.17 & 0.09 & Table 6 \\
345 & 0.30 & 0.34 & 0.66 & 0.20 & 0.10 & Table 6 \\
345 & 0.35 & 0.34 & 0.66 & 0.23 & 0.12 & Table 6 \\
345 & 0.40 & 0.46 & 0.54 & 0.22 & 0.18 & Table 6 \\
345 & & & & $\mathbf{0 . 1 8}$ & & average \\
\hline
\end{tabular}

Level change from $260 "$ to $160 "$

\begin{tabular}{|c|c|c|c|c|c|c|}
\hline $\begin{array}{c}\text { Saltcake } \\
\text { level } \\
\text { (in) }\end{array}$ & $\begin{array}{c}\text { void } \\
\text { fraction/ } \\
\text { total porosity } \\
\theta\end{array}$ & $\begin{array}{c}\text { residual } \\
\text { saturation } \\
\mathrm{S}_{\mathrm{r}}\end{array}$ & $\begin{array}{c}\text { drainable } \\
\text { saturation } \\
1-S_{r}\end{array}$ & $\begin{array}{c}\text { drainable } \\
\text { liquid } \\
\text { fraction of } \\
\text { total volume } \\
\theta\left(1-S_{r}\right)\end{array}$ & $\begin{array}{c}\text { residual } \\
\text { liquid } \\
\text { fraction of } \\
\text { total volume } \\
\theta S_{r}\end{array}$ & Comments \\
\hline 350 & 0.15 & 0.14 & 0.86 & 0.13 & 0.02 & Table 5 \\
\hline 350 & 0.25 & 0.34 & 0.66 & 0.17 & 0.09 & Table 5 \\
\hline 350 & 0.35 & 0.46 & 0.54 & 0.19 & 0.16 & Table 5 \\
\hline 350 & & & & 0.16 & & average \\
\hline 345 & 0.15 & 0.14 & 0.86 & 0.13 & 0.02 & Table 6 \\
\hline 345 & 0.20 & 0.21 & 0.79 & 0.16 & 0.04 & Table 6 \\
\hline 345 & 0.25 & 0.34 & 0.66 & 0.17 & 0.09 & Table 6 \\
\hline 345 & 0.30 & 0.46 & 0.54 & 0.16 & 0.14 & Table 6 \\
\hline 345 & 0.35 & 0.46 & 0.54 & 0.19 & 0.16 & Table 6 \\
\hline 345 & 0.40 & 0.49 & 0.51 & 0.20 & 0.20 & Table 6 \\
\hline 345 & & & & 0.17 & & average \\
\hline
\end{tabular}




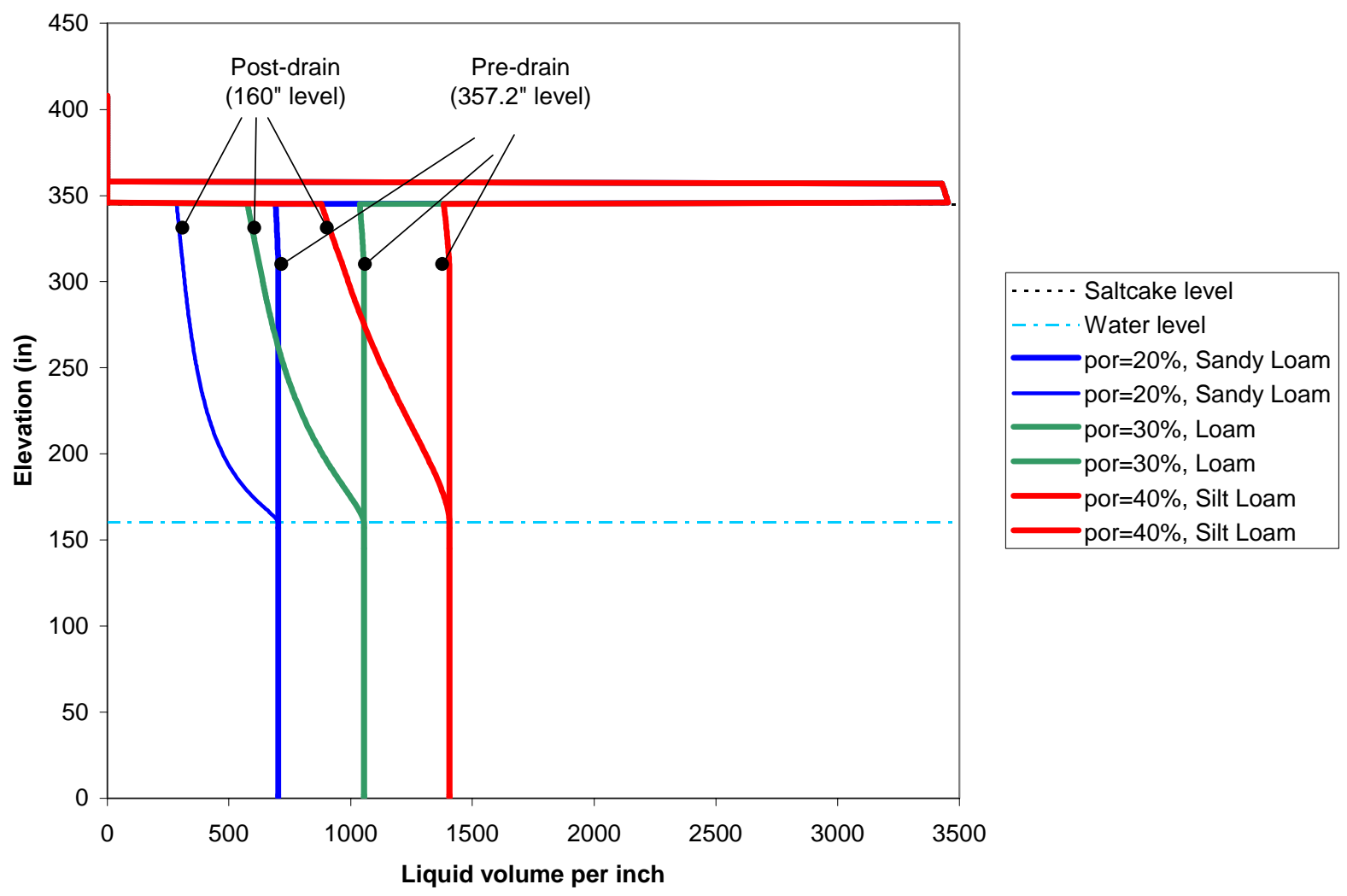

Figure 7 Liquid inventories in Tank 41 before and after pumping for three optimal parameter settings (345" saltcake level). 
Table 9 Example combinations of initial and residual liquid content that are consistent with a $14 \%$ drainable liquid content; equivalent calculations shown for radiolytic gas excluded from and included in voids.

\begin{tabular}{|c|c|c|c|c|c|}
\hline \multirow{2}{*}{$\begin{array}{c}\text { Initial water } \\
\text { content in } \\
\text { submerged } \\
\text { saltcake } \\
\theta_{\text {ws }}\end{array}$} & \multicolumn{5}{|c|}{ Radiolytic gas lumped with salt - excluded from "voids" } \\
\hline & $\begin{array}{c}\text { Pseudo total } \\
\text { porosity } \\
\text { n' }\end{array}$ & $\begin{array}{c}\text { Drainable } \\
\text { liquid content } \\
\left.\text { n'(1-S } S_{w r}^{\prime}\right)\end{array}$ & $\begin{array}{c}\text { Residual } \\
\text { liquid content } \\
\text { n'S }_{\mathrm{wr}}{ }^{\prime}\end{array}$ & $\begin{array}{l}\text { Pseudo } \\
\text { residual } \\
\text { saturation } \\
\mathrm{S}_{\mathrm{wr}}\end{array}$ & $\begin{array}{c}\text { Pseudo } \\
\text { drainable } \\
\text { saturation } \\
1-S_{w r}\end{array}$ \\
\hline 0.20 & 0.20 & 0.14 & 0.06 & 0.30 & 0.70 \\
\hline 0.25 & 0.25 & 0.14 & 0.11 & 0.44 & 0.56 \\
\hline 0.30 & 0.30 & 0.14 & 0.16 & 0.53 & 0.47 \\
\hline 0.35 & 0.35 & 0.14 & 0.21 & 0.60 & 0.40 \\
\hline 0.40 & 0.40 & 0.14 & 0.26 & 0.65 & 0.35 \\
\hline
\end{tabular}

\begin{tabular}{|c|c|c|c|c|c|c|c|c|}
\hline & Radiolytic ga & included in voi & id space & & & & & \\
\hline $\begin{array}{c}\text { submerged } \\
\text { saltcake } \\
\theta_{\text {ws }}\end{array}$ & $\begin{array}{c}\text { Initial gas } \\
\text { content } \\
\theta_{\mathrm{g}} \\
\end{array}$ & $\begin{array}{c}\text { Total porosity } \\
\mathrm{n}\end{array}$ & $\begin{array}{c}\text { Drainable } \\
\text { liquid content } \\
\mathrm{n}\left(\mathrm{S}_{\mathrm{ws}}-\mathrm{S}_{\mathrm{wr}}\right)\end{array}$ & $\begin{array}{c}\text { Residual } \\
\text { liquid content } \\
\mathrm{nS}_{\mathrm{wr}}\end{array}$ & $\begin{array}{c}\text { Initial } \\
\text { saturation } \\
\mathrm{S}_{\mathrm{ws}}\end{array}$ & $\begin{array}{c}\text { Residual } \\
\text { saturation } \\
\mathrm{S}_{\mathrm{wr}}\end{array}$ & $\begin{array}{c}\text { Drainable } \\
\text { saturation } \\
\mathrm{S}_{\mathrm{ws}}-\mathrm{S}_{\mathrm{wr}}\end{array}$ & $\begin{array}{c}\text { Gas } \\
\text { saturation } \\
\mathrm{S}_{\mathrm{g}}\end{array}$ \\
\hline 0.20 & 0.105 & 0.31 & 0.14 & 0.06 & 0.66 & 0.20 & 0.46 & 0.34 \\
\hline 0.25 & 0.105 & 0.36 & 0.14 & 0.11 & 0.70 & 0.31 & 0.39 & 0.30 \\
\hline 0.30 & 0.105 & 0.41 & 0.14 & 0.16 & 0.74 & 0.40 & 0.35 & 0.26 \\
\hline 0.35 & 0.105 & 0.46 & 0.14 & 0.21 & 0.77 & 0.46 & 0.31 & 0.23 \\
\hline 0.40 & 0.105 & 0.51 & 0.14 & 0.26 & 0.79 & 0.51 & 0.28 & 0.21 \\
\hline
\end{tabular}

\section{Analysis of dynamic tank liquid levels during drain operations}

The above static analysis was possible because an equilibrium tank level could be estimated from recovery data acquired during unplanned downtime due to an equipment problem. In general, the tank may not be at equilibrium and the liquid level will differ across Tank 41. In Tank 41 the well is located near the tank wall, so during drainage the liquid level will be lowest at the well and highest at the far wall. A rigorous estimate of the interstitial liquid level across the tank requires numerical simulation. However, the mean liquid level can be approximately estimated from the pumping rate and well level under pseudo-steady conditions using a simple analytical approach, as shown below. The motivation for estimating the mean tank level is two-fold. First, the mean tank level should be a reasonable surrogate for the maximum level, as shown schematically in Figure 8 . The difference between the well water level and the maximum water level is an indication of the overall gradient across the tank. Second, the mean tank level would also be the equilibrium tank level after transients subside. A projection of the equilibrium water level could be useful for performing liquid inventory calculations, such as performed in the preceding section. The semi-empirical relationship of mean tank level to well level and pumping rate developed herein can also be used to estimate drainage times when the well level is held at a long-term low (e.g. minimum) level, as shown below. 


\section{Average tank level estimation}

Analytical solutions of steady-state, unconfined, porous media flow in a variety of radial and rectangular geometries have the form

$$
h(\vec{x})^{2}-h_{r e f}^{2}=\frac{\mu}{k \rho g} Q \cdot C_{g e o m}(\vec{x})
$$

where $h(\vec{x})$ is water level at location $\vec{x}, h_{\text {ref }}$ is a reference water level, $C_{g e o m}(\vec{x})$ is a geometric function, $k$ is intrinsic permeability, $\mu$ is viscosity, $\rho$ is density, $g$ is gravitational acceleration, and $Q$ is a constant pumping or flow rate. A well-known example is the Dupuit-Forchheimer formula for well discharge (cf. de Marsily, 1986, p. 150)

$$
h^{2}-h_{r e f}^{2}=\frac{\mu}{k \rho g} Q \cdot \frac{1}{\pi} \ln \frac{r}{r_{r e f}}
$$

where $r$ is the radial distance from the well, and $r_{r e f}$ is the radius of the boundary where $h=h_{r e f}$. The average of water level squared can be readily computed from equation (26) as

$$
\overline{h^{2}}=h_{r e f}^{2}+\frac{\mu}{k \rho g} Q \cdot \overline{C_{g e o m}}
$$

and then

$$
h(\vec{x})^{2}-\overline{h^{2}}=\frac{\mu}{k \rho g} Q \cdot\left[C_{g e o m}(\vec{x})-\overline{C_{\text {geom }}}\right]
$$

For a given well location, porous medium, and fluid properties, equation (29) can be simplified as

$$
h_{w}^{2}-\overline{h^{2}}=\frac{Q}{C}
$$

where the constant $C$ can be treated as an empirical constant to be estimated from data. Assuming the head gradient at the well under the conditions of interest is not too large

$$
\overline{h^{2}} \cong \bar{h}^{2}
$$

and then equation (30) can be replaced by the approximation 


$$
h_{w}^{2}-\bar{h}^{2}=\frac{Q}{C}
$$

Equation (32) is assumed to be approximately valid for the tank and well configuration of Tank 41. With some approximation, the expression should also be valid under pseudosteady conditions, i.e. slow transients. Thus, the latter portion of the drawdown transient from $9 / 8 / 02$ through $9 / 22 / 02$ can be used to determine $C$. During this period, the pumping rate averaged $3.19 \mathrm{gpm}$, while the well and mean (equilibrium) tank levels were inferred above to be approximately 227.6" and 260", respectively. As shown in Table 10, these inputs produce an estimate of $C=Q / \Delta h^{2}=2.02 \times 10^{-4} \mathrm{gpm} / \mathrm{in}^{2}$.

Example solutions of equation (32) are shown in Figure 9 to illustrate the behavior of the flow model with respect to different pumping rates. For example, at a pumping rate of 5 gpm and a well level of 200", the average or equilibrium tank level is estimated from equation (32) to be 254". At the pumping rate of $1 \mathrm{gpm}$ and a well level of 200", the mean tank level is predicted to be $212 "$.

Recovery data from Phase II (Figure 1) provide an opportunity to validate expression (32). Over the three days prior to the second major well recovery, 11/8 through $11 / 10$ inclusive, a net volume of 3725 gallons was removed from Tank 41. The average removal rate was thus 0.86 gpm. Going into recovery, the well level was 130". Equation (32) predicts an equilibrium well level of 145". Two weeks later, the well level had recovered to $147 "$ and appeared to be leveling off. By three weeks, the level was at 150". Since then however, the well level has risen at roughly a constant, rather than, declining rate. At the end of the data record, the well level was 157"on 12/9.

The shape of the recovery curve suggests two phenomena are having an impact. The first is a leveling of the interstitial liquid level across the tank. The second is continued drainage of liquid from unsaturated saltcake above the interstitial liquid level. Equation (32) considers only the first phenomenon, which probably dominates in the early stage of well recovery. In this respect, equation (32) appears to have predicted the short-term recovery level with reasonable accuracy. Over longer time scales, equation (32) appears to under-predict well recovery, due to small amounts of additional drainage from saltcake above the interstitial level. A more sophisticated (i.e. numerical) modeling approach would be needed to more accurately predict well recovery.

Another contributing factor to discrepancy between the model and recovery data could be changes in the well diameter. The analysis assumes a constant diameter well. If the well diameter is smaller in the lower portion of the well where the second recovery occurred, the rebound would have been greater because the gradients in the radially converging flow would have been steeper. 


\section{Drain time estimation}

When the well liquid level is lowered to some minimum elevation near the tank bottom, and maintained through continued pumping, drainage to the well will occur at a continually slower rate as the head gradient across the tank declines. The time required to further lower the current mean level to a particular desired level can be roughly estimated by combining equation (32) with the mass balance

$$
Q(t)=\frac{d \bar{h}}{d t} A n-\frac{d \bar{h}}{d t} A n S_{w r}=\frac{d \bar{h}}{d t} A n\left(1-S_{w r}\right)
$$

which equates the pumping rate from the well to the rate of change in liquid inventory. The right-hand side of the expression is rate of decrease of saturated saltcake minus the rate of gain of saltcake at residual saturation. Although, equation (32) was developed assuming a constant pumping rate, as stated earlier, it should also be approximately valid under pseudo-steady conditions (slow transients). If equations (32) and (33) are combined by eliminating $Q$ under this assumption, the result is an ordinary differential equation in terms of mean tank level, given a fixed well level and porous medium properties:

$$
h_{w}^{2}-\bar{h}^{2}=\frac{A n\left(1-S_{w r}\right)}{C} \frac{d \bar{h}}{d t}
$$

Defining

$$
C^{\prime}=\frac{A n\left(1-S_{w r}\right)}{C}
$$

results in the simplified expression

$$
h_{w}^{2}-\bar{h}^{2}=C^{\prime} \frac{d \bar{h}}{d t}
$$

The solution can be derived by separating variables

$$
d t=\frac{C^{\prime}}{h_{w}^{2}-\bar{h}^{2}} d \bar{h}
$$

Equation (37) can then be integrated as 


$$
\begin{aligned}
& \int_{t_{0}}^{t} d t=\int_{\bar{h}_{0}}^{\bar{h}} \frac{C^{\prime}}{h_{w}^{2}-\bar{h}^{2}} d \bar{h} \\
& t-t_{0}=C^{\prime} \int_{\overline{h_{0}}}^{\bar{h}} \frac{d \bar{h}}{h_{w}^{2}-\bar{h}^{2}} \\
& t-t_{0}=-C^{\prime} \int_{\bar{h}_{0}}^{\bar{h}} \frac{d \bar{h}}{\bar{h}^{2}-h_{w}^{2}}
\end{aligned}
$$

Using integral formula \#18 in the 27th edition of the CRC Standard Mathematical Tables,

$$
\begin{aligned}
& t-t_{0}=-\left.C^{\prime} \frac{1}{2 h_{w}} \log \frac{\bar{h}-h_{w}}{\bar{h}+h_{w}}\right|_{\bar{h}_{0}} ^{\bar{h}} \\
& \Delta t=\frac{C^{\prime}}{2 h_{w}}\left[\log \frac{\bar{h}_{0}-h_{w}}{\bar{h}_{0}+h_{w}}-\log \frac{\bar{h}-h_{w}}{\bar{h}+h_{w}}\right]
\end{aligned}
$$

where $h_{w}>0$. If the well level is zero, the result is

$$
\Delta t=-C^{\prime} \int_{\bar{h}_{0}}^{\bar{h}} \frac{d \bar{h}}{\bar{h}^{2}}=-\left.C^{\prime} \frac{\bar{h}^{-1}}{-1}\right|_{\bar{h}_{0}} ^{\bar{h}}=\left.C^{\prime} \frac{1}{\bar{h}}\right|_{\bar{h}_{0}} ^{\bar{h}}=C^{\prime}\left[\frac{1}{\bar{h}}-\frac{1}{\bar{h}_{0}}\right]
$$

Equation (39) or (40) provides a crude estimate of the time required to drain Tank 41 when the well water level is maintained at some constant, minimum feasible, height. The drainage time is seen to depend on the well level, initial mean tank level, the desired final mean tank level.

An example set of solutions for an initial mean tank level of 48 " is shown in Figure 10 for illustrative purposes. In this example, if the well level is maintained at 10" and the desired final average tank level is $36 "$ ", then the drainage time is projected to be on the order of 15 days. If the desired final average tank height is 24", the drain time becomes 50 days. Because a number of assumptions and approximations are built into equations (39) and (40), the accuracy of estimates such as those depicted in Figure 11 is not known. Lacking quantitative validation of these expressions through numerical modeling and/or field experience, drain times from these expressions should be viewed as order-of-magnitude estimates. 


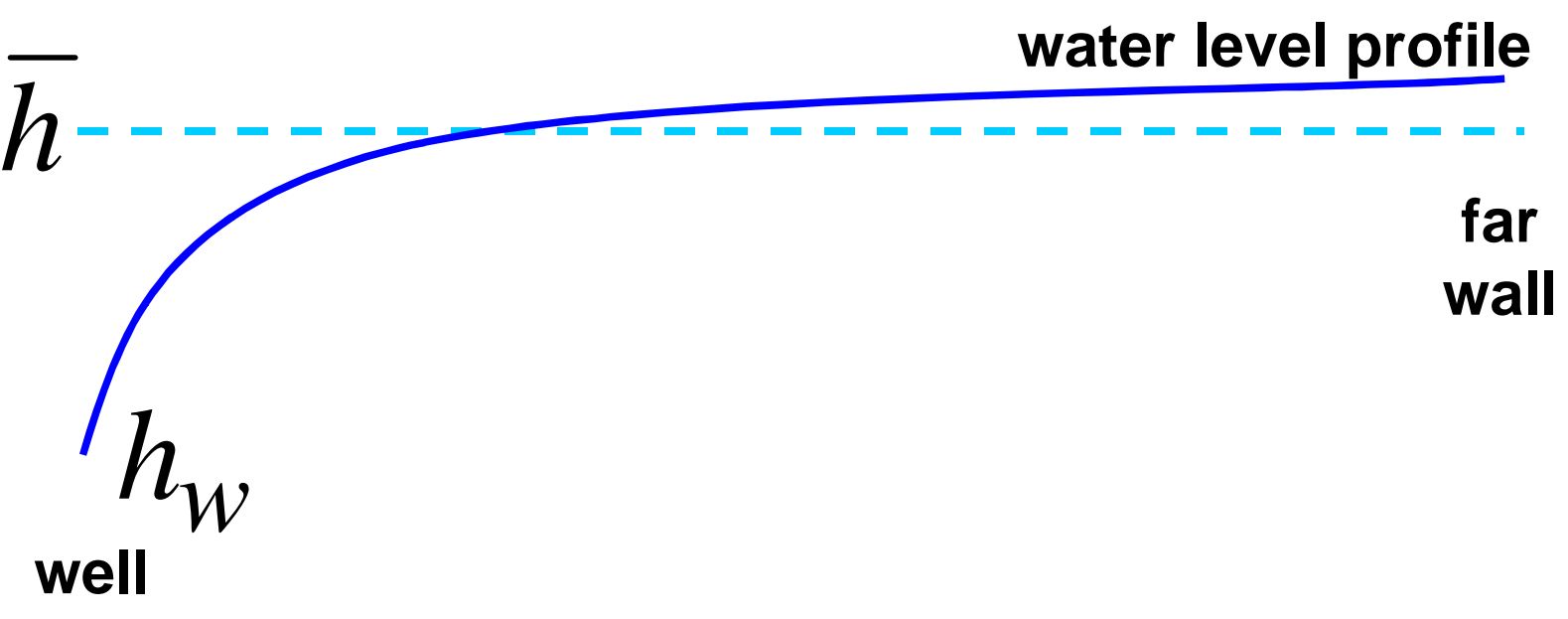

Figure $8 \quad$ Schematic representation of interstitial liquid level across Tank 41.

Table 10. Calibration of pseudo-steady flow solution to Tank 41 data.

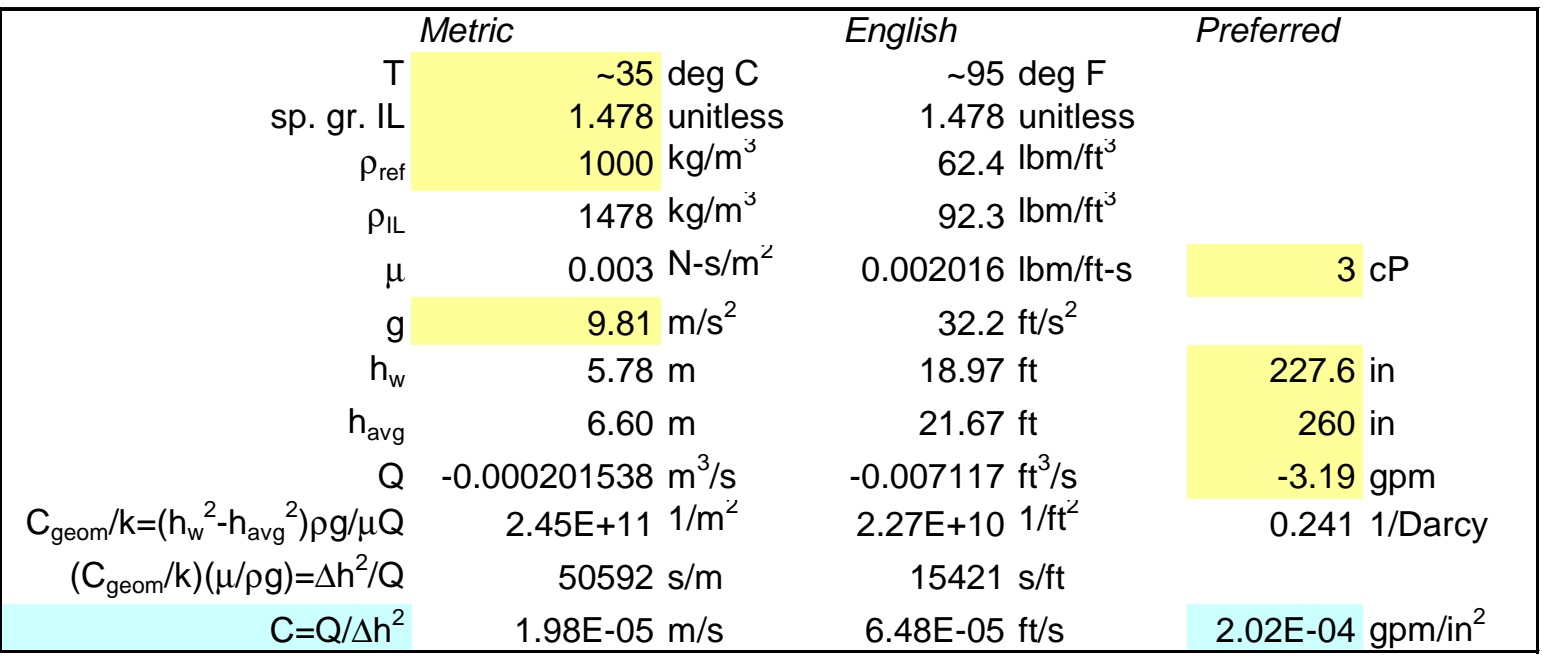


Tank 41

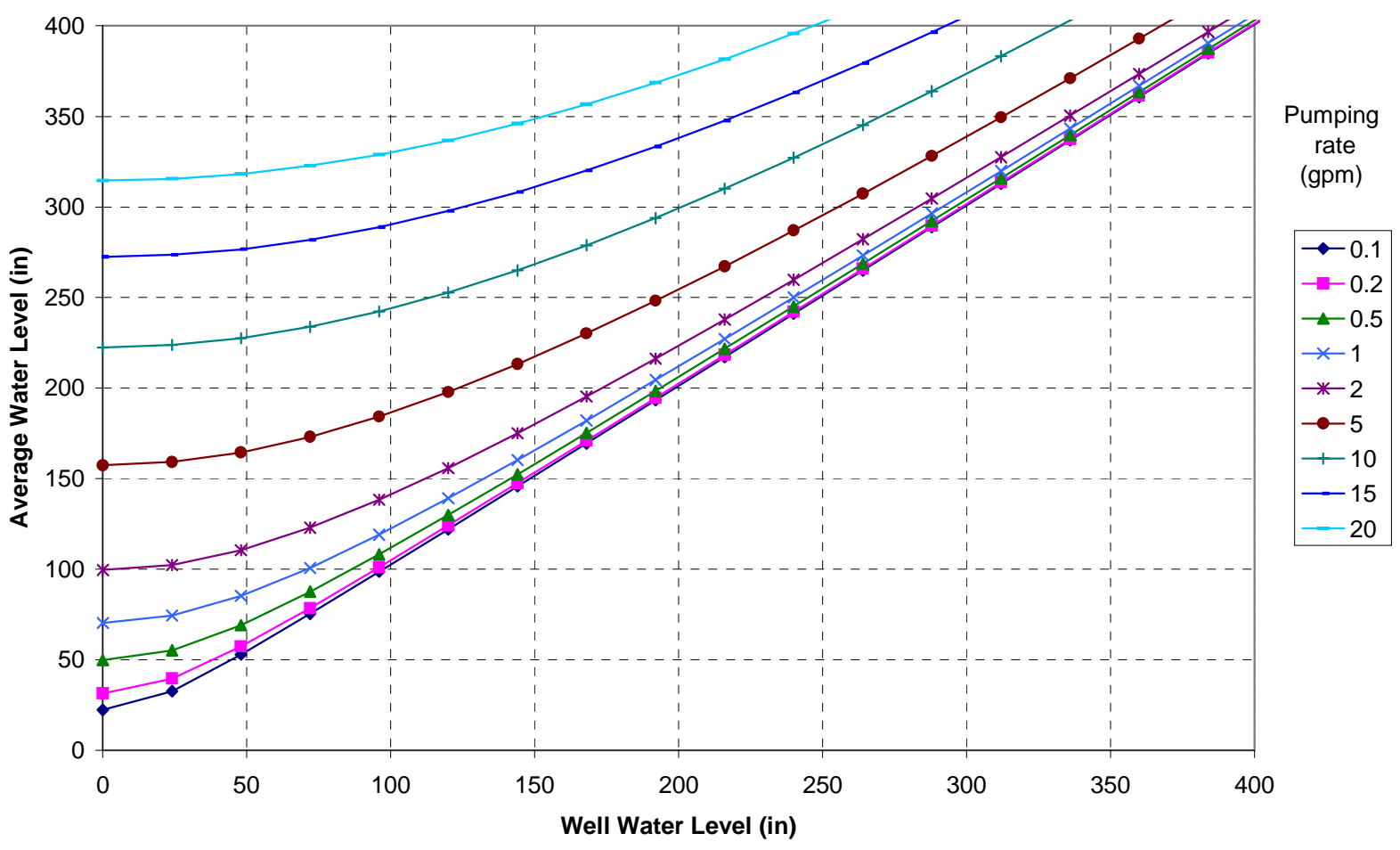

Figure 9 Pseudo-steady flow solutions for Tank 41. 
Tank 41

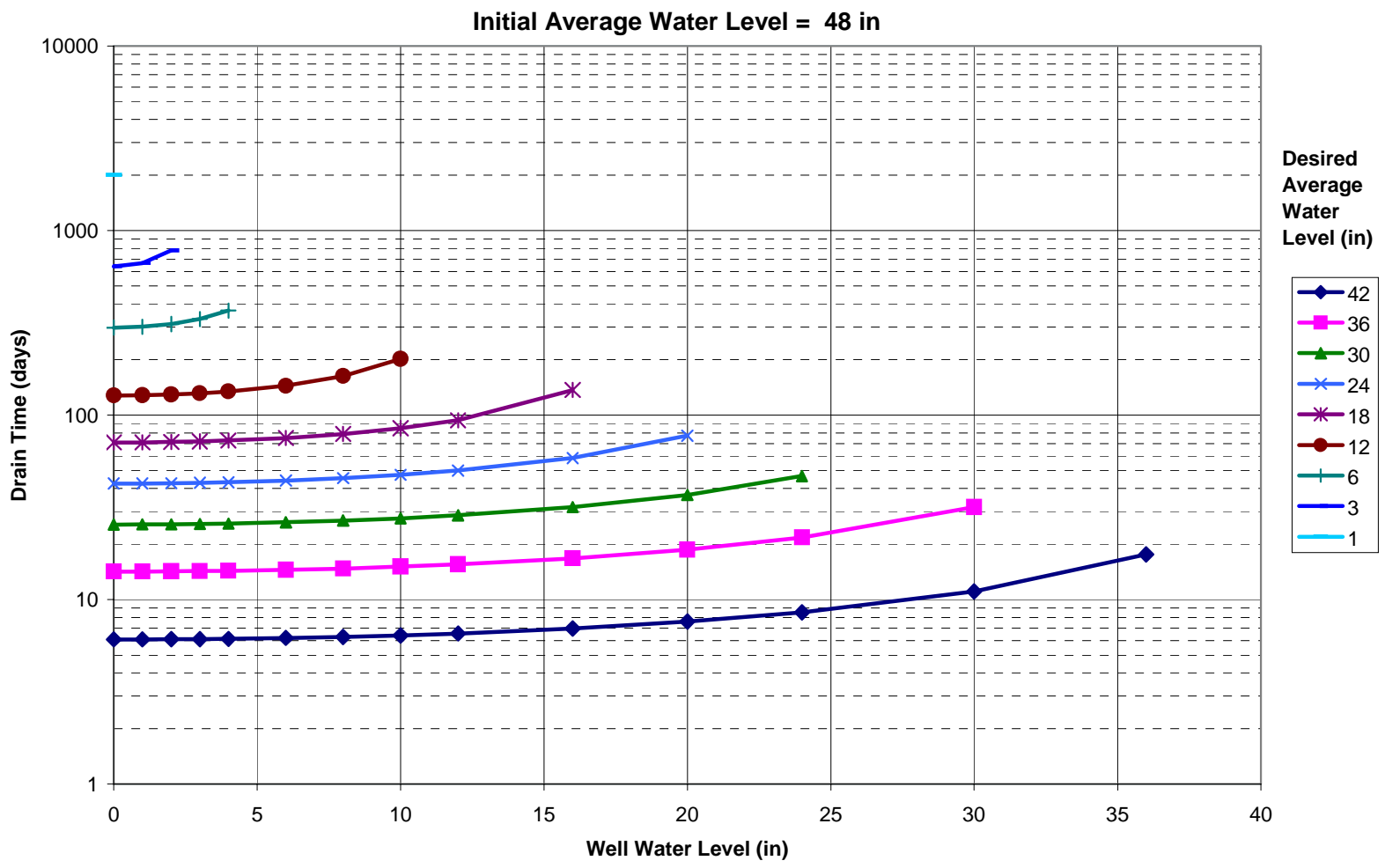

Figure 10 Estimated drainage time starting from a mean tank level of 48". 


\section{References}

de Marsily, G., 1986, Quantitative hydrogeology; groundwater hydrology for engineers, Academic Press, Orlando, 440 p.

Fowler, J. R., 1982, Composition of $\mathrm{H}$ area and SRP soluble high-level waste, DPST-82502

Hester, J. R., 2001, Re-evaluation of level-barometric pressure measurements of bubble gas volumes in high level waste, WSRC-TR-2001-00068.

Hester, J. R., 2002, Tank 41H low curie salt removal hydrogen release evaluation, WSRC-TR-2002-00164.

Looney, B.B., and R.W. Falta, eds., 2000, Vadose Zone Science and Technology Solutions, Battelle Press, Columbus, OH, 1540 p.

Pike, J. A., M. D. Drumm, S. G. Subosits, J. L. Statton, F. A. Washburn, 2001, Feed basis for processing relatively low radioactivity waste tanks, WSRC-TR-2001-00559, Rev. 1.

Pike, J. A., 2002, Tank 41 salt dissolution flowsheet modeling, WSRC-TR-2002-00209, Rev. 0.

Romanowski, L. B., 2002, Low curie salt processing technical plan, HLW-SDT-200200031, Rev. 0.

Schaap, M. G., and F. J. Leij, 1998, Database-related accuracy and uncertainty of pedotransfer functions, Soil Science, v 163, n 10, 765-779.

Task Technical Request HLE-TTR-2003-057, Rev. 1.

van Genuchten, M. Th., 1980, A closed-form equation for predicting the hydraulic conductivity of unsaturated soils, Soil Sci. Am. J., v 44, 892-898.

Wiersma, B. J., 1996, Recommendations for the use of inhibited water during Phase I salt dissolution in Tank 41, WSRC-TR-96-0085. 
This page intentionally left blank 